\title{
The Archaeological Findings from the East Texas Archeological Society 2018 Field Day at the Bowles Creek Site (41CE475), Cherokee County, Texas
}

Timothy K. Perttula

Kevin Stingley

Heritage Center of Cherokee County

Follow this and additional works at: https://scholarworks.sfasu.edu/ita

Part of the American Material Culture Commons, Archaeological Anthropology Commons, Environmental Studies Commons, Other American Studies Commons, Other Arts and Humanities Commons, Other History of Art, Architecture, and Archaeology Commons, and the United States History Commons

Tell us how this article helped you.

This Article is brought to you for free and open access by the Center for Regional Heritage Research at SFA ScholarWorks. It has been accepted for inclusion in Index of Texas Archaeology: Open Access Gray Literature from the Lone Star State by an authorized editor of SFA ScholarWorks. For more information, please contact cdsscholarworks@sfasu.edu. 
The Archaeological Findings from the East Texas Archeological Society 2018 Field Day at the Bowles Creek Site (41CE475), Cherokee County, Texas

\section{Creative Commons License}

\section{(c) (1) \&}

This work is licensed under a Creative Commons Attribution-NonCommercial 4.0 International License 


\section{The Archaeological Findings from the East Texas Archeological Society 2018 Field Day at the Bowles Creek Site (41CE475), Cherokee County, Texas}

Timothy K. Perttula and Kevin Stingley

\section{Introduction}

The Bowles Creek site is a substantial Historic Caddo period Allen phase settlement on a natural rise in the Bowles Creek floodplain in the Neches River basin in East Texas (Figure 1). There have been several rounds of work completed at the site, and other ancestral Caddo sites in the Bowles Creek valley since the Bowles Creek site was first recorded by Stingley, including intensive shovel testing, the excavation of a number of $1 \mathrm{x} 1 \mathrm{~m}$ units in various parts of the site, and the remote sensing of a 2400 square meter area in the southern part of the site (McKinnon 2017; Perttula and Stingley 2016a-b, 2017a-b; Perttula et al. 2016, 2017; Stingley and Perttula 2017). In this article, we discuss the archaeological findings from work done at the site in May 2018 by the East Texas Archeological Society.

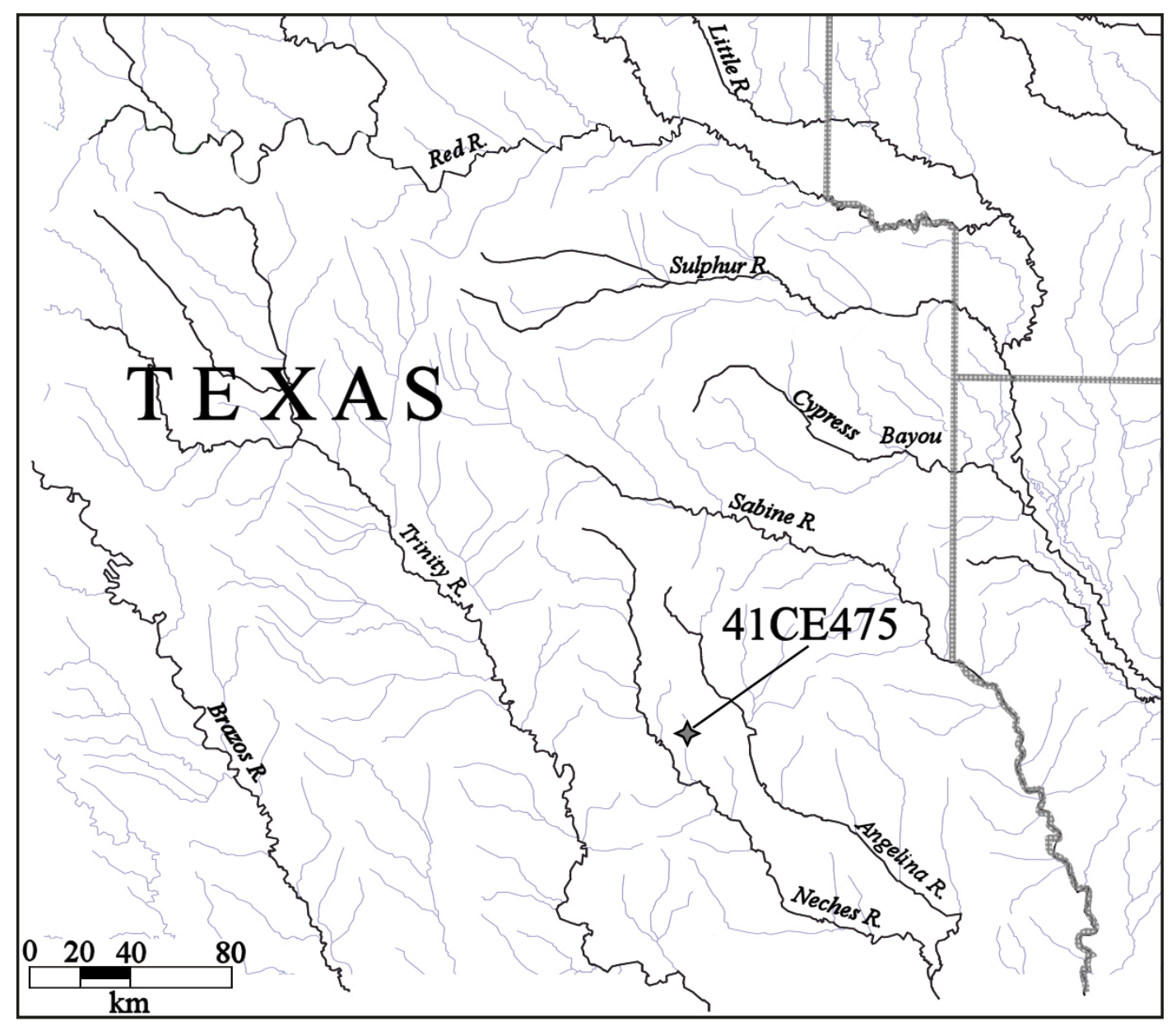

Figure 1. Location of the Bowles Creek site (41CE475) in East Texas. 
The past work done at the Bowles Creek site indicates that it is a component of the Historic Caddo Neche cluster of ceramic vessel sherd assemblages; this includes several Allen phase Historic Caddo sites on Bowles Creek and the Neches River (41CE291) as well as one Late Frankston phase (ca. A.D. 1560-1680) investigated component of the George C. Davis site (41CE19) (Fields and Thurmond 1980) on the northern part of the terrace east of the Neches River. These components have high proportions of brushed sherds and ratios of brushed to other wet paste sherds (Perttula 2016:Table 3). These assemblages are primarily sherds from grog-tempered vessels, but differences between the sites in the proportion of bone-tempered vessels (either as the sole temper or in combination with grog) suggest that two contemporaneous groups of Allen phase sites are present in the Neche cluster. These two groups (I and II) also are notably different in brushed to plain sherd ratios; the Bowles Creek site is included in Group II of the Neche cluster because of its higher proportion of bone-tempered sherds (10.5 percent), its P/DR (0.40), and the ratio of brushed to plain sherds (2.07) (Perttula et al. 2017:Table 7).

Other artifacts that are present in the assemblage from previous archaeological investigations at the Bowles Creek site include sherds from several plain and decorated elbow pipes, a unifacially flaked Cuney arrow point, a ground stone tool, and small amounts of lithic debris, burned and unburned animal bone, and a few pieces of wood charcoal. No European trade goods have been recovered from the Bowles Creek site during the several phases of shovel testing and $1 \times 1 \mathrm{~m}$ unit excavations, suggesting the Allen phase component predates ca. A.D. 1720, when European trade goods become more abundant in Historic Caddo sites in the Neches and Angelina River basins (cf. Cole 1975; Jackson et al. 1720; Kenmotsu 1992; Perttula et al. 2010; Prewitt 2018; Story 1982, 1995).

\section{Previous Investigations at the Bowles Creek Site (41CE475)}

There have been several phases of archaeological work conducted in the last few years at the Bowles Creek site under the direction of Kevin Stingley. These include surface collections (Perttula et al. 2016; Perttula and Stingley 2016a), intensive shovel testing - 59 shovel tests have been excavated that contained archaeological deposits (Perttula et al. 2016:Figure 12; Perttula and Stingley 2017a:Figure 2, 2017b:Figures 2 and 5, 2017d:Figure 1), most in the southern part of the site, and approaching the Bowles Creek channel (Figure 2) - and the excavation of six 1 x 1 m units, three (BC-2, BC-3, and BC-4) in the southern part of the site (Perttula et al. 2016; Perttula and Stingley 2017a, 2017d). The archaeological deposits range to upwards of $100 \mathrm{~cm}$ bs, and there are dark brown sandy loam anthropogenic deposits with flecks of charcoal in Unit BC-3 (see Figure 2).

The remote sensing of 2400 square meters in the southern part of the Bowles Creek site was completed by Dr. Duncan P. McKinnon of the University of Central Arkansas in early 2016 (see Figure 2). That work identified two possible ancestral Caddo structures in the eastern and central part of the grid (Figure 3), along with a semi-circular arc of possible post holes ca. $12 \mathrm{~m}$ in diameter in the south central grid.

The densities of ceramic vessel sherds (Figure 4a), animal bones (Figure 4b), and charred plant remains (Figure $4 \mathrm{~b}$ ) have been plotted from the shovel tests excavated in the remote sensing grid, as well as ca. $10 \mathrm{~m}$ south of the grid and approaching the Bowles Creek channel. They indicate that there is a ca. $40 \times 20 \mathrm{~m}$ area at the southern end of the site that has a high density of material culture remains (i.e., 15-29 ceramic vessel sherds per shovel test) as well as a ca. $20 \times 20 \mathrm{~m}$ area within it that has preserved animal bones and charred plant remains in shovel tests.

In addition to anthropogenic deposits in Unit BC-3, several more discrete features have been identified in the work at the Bowles Creek site. These include two post holes in Unit BC-2 that were exposed between 40-94 cm bs (Perttula and Stingley 2017a), an area with burned clay and ash chunks in ST 61, likely the remnants of a Caddo house structure, hearth, or large pit (Perttula and Stingley 2017b:116), and a thick ash zone (60-75 cm bs) in ST 100 (Perttula and Stingley 2017d). These features are concentrated in a relatively small area (ca. $8 \times 2 \mathrm{~m})$ in the south central part of the remote sensing grid and a few meters south of the grid (see Figure 2). 


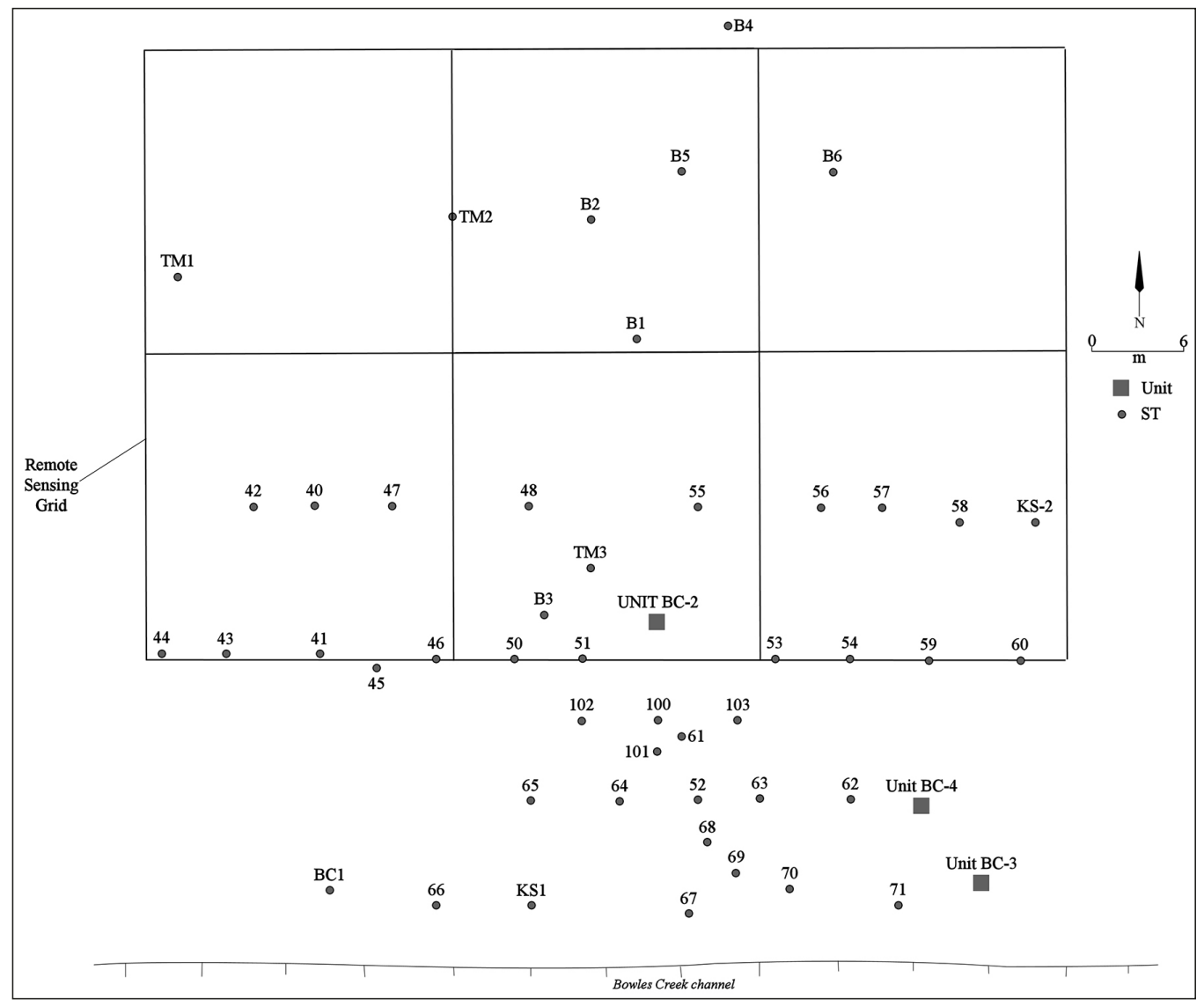

Figure 2. Shovel tests, 1 x $1 \mathrm{~m}$ units, and remote sensing grid at the Bowles Creek site before the 2018 East Texas Archeological Society work.

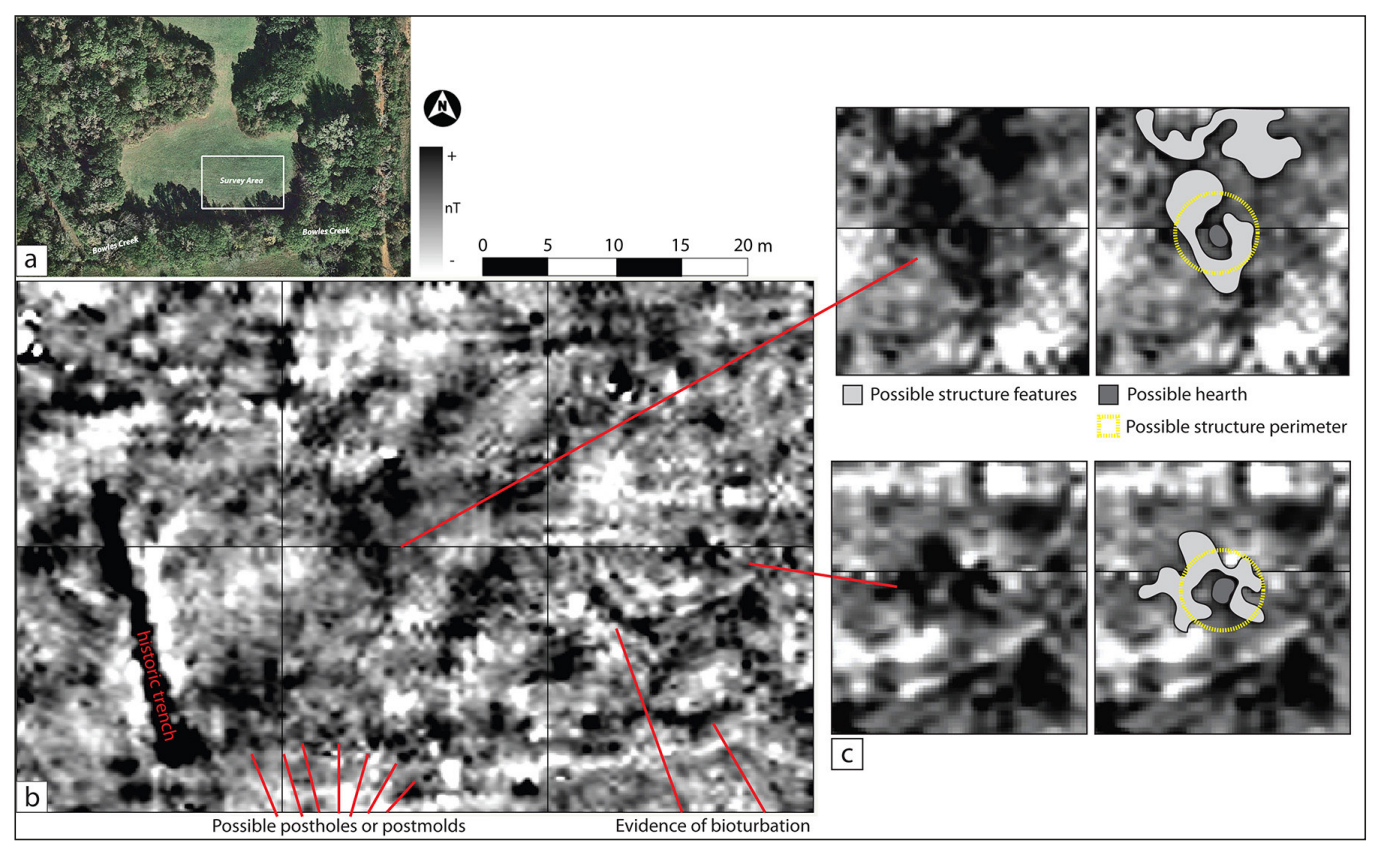

Figure 3. Results of the remote sensing work at the Bowles Creek site (from McKinnon 2017:Figure 3). 

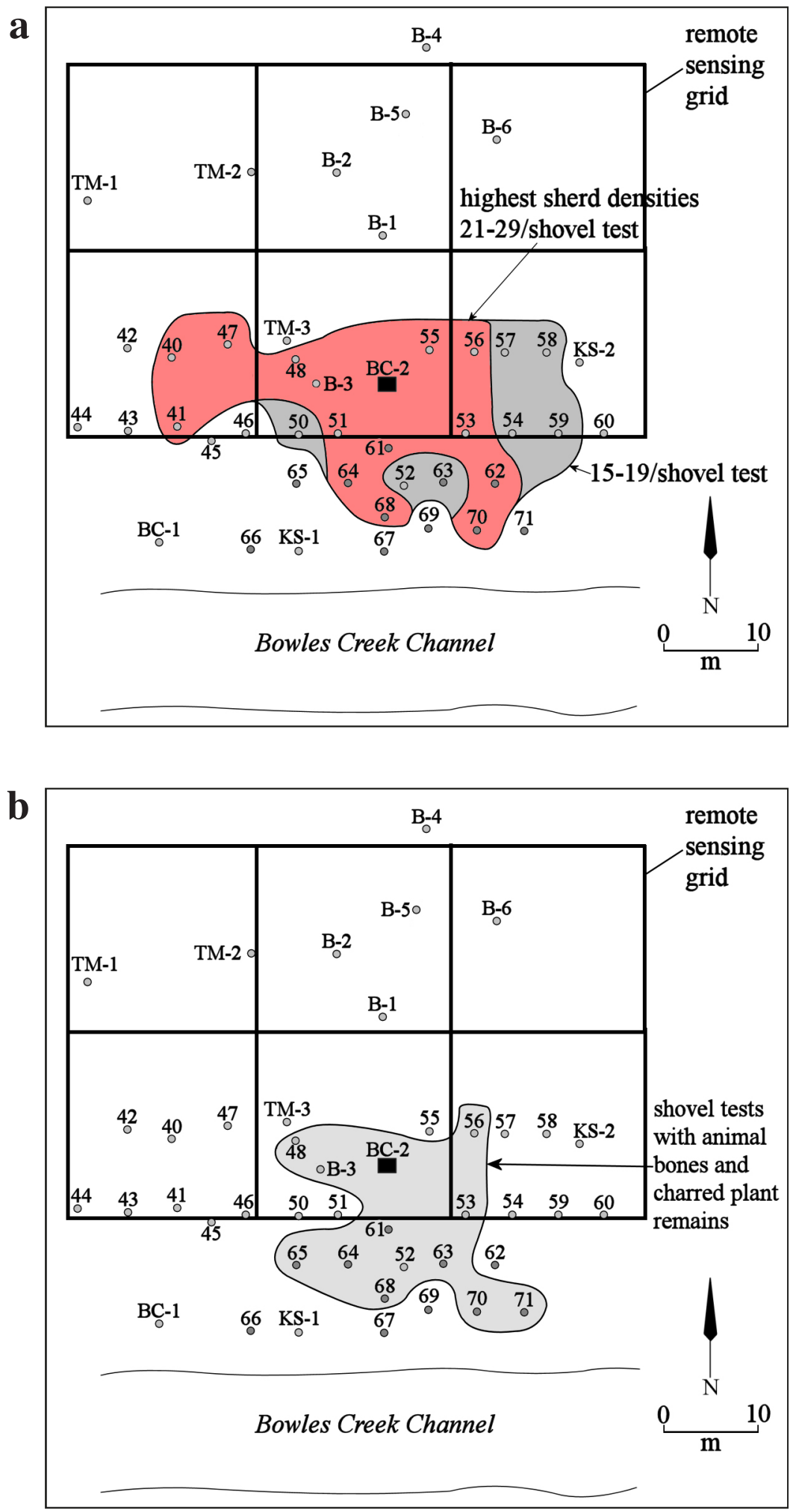

Figure 4. Densities of material culture remains in and south of the remote sensing grid at the Bowles Creek site: a, highest sherd densities; b, shovel tests with animal bones and charred plant remains. 


\section{East Texas Archeological Society Investigations}

The East Texas Archeological Society investigations at the Bowles Creek site were under the direction of Dr. Tom Middlebrook, President of the society and a member of the Texas Historical Commission's Archeological Stewardship Network. Kevin Stingley was his assistant during the field work. There were five crews of participants (Figure 5) in the excavations of six different $1 \times 1 \mathrm{~m}$ units:

Crew 1 (Unit 2 and Unit 5): Mark Walters (crew chief), Tom Gann, Milton Moorer, and Lonnie Lindsey;

Crew 2 (Unit 1): Bo Nelson (crew chief), Matthew DeWard, Jimmy Partin, and Morgan Tingle;

Crew 3 (Unit 6): George Avery (crew chief), Barbara Chadwick, David Ivy, and Geoff Anderson;

Crew 4 (Unit 4): Ron Coleman (crew chief), Tom Yarborough, Edward Pounders, Kirsten Pounders; and

Crew 5 (Unit 3): Morris Jackson (crew chief), Anne Tindell, Pam Neeley, and Winston Bolinger.

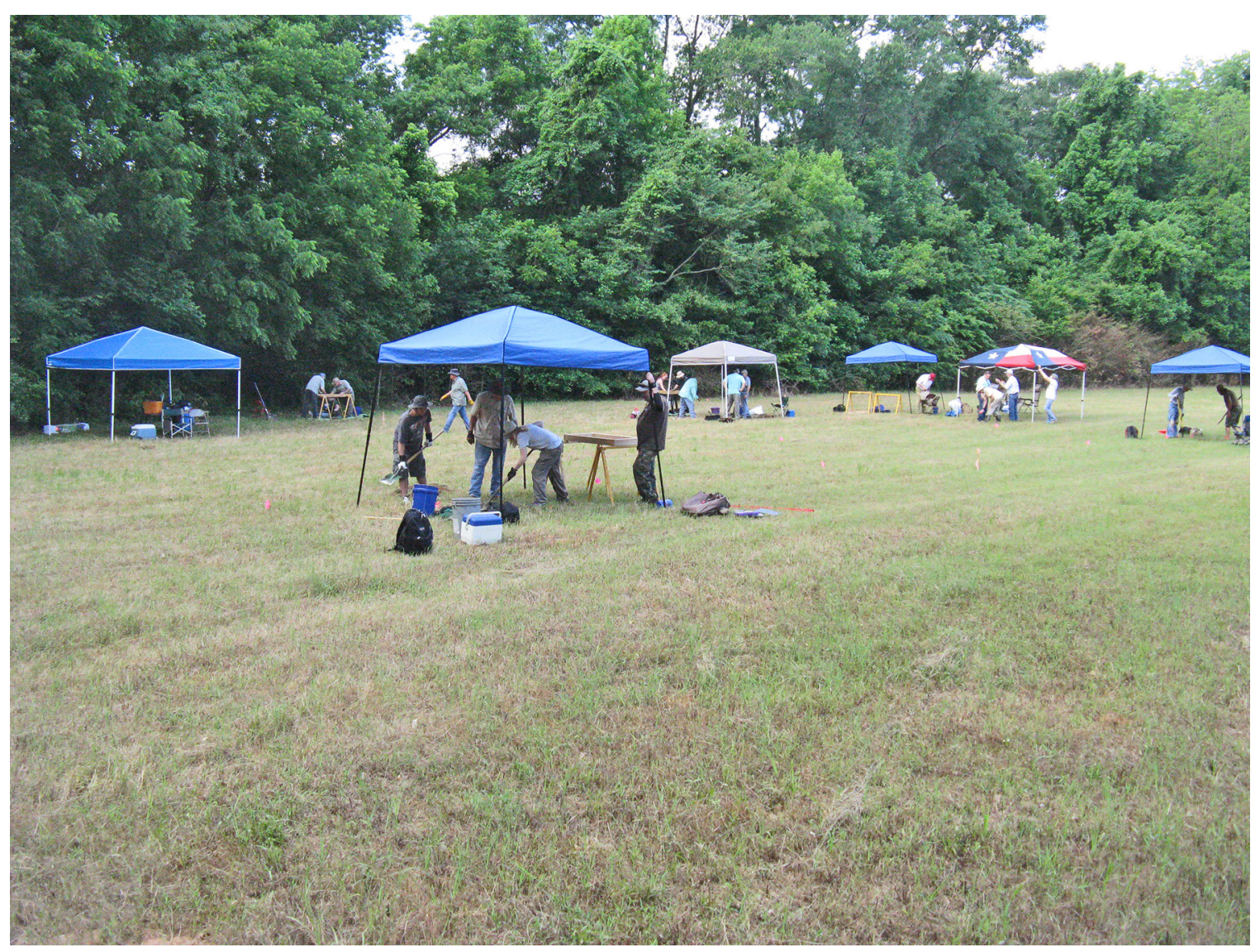

Figure 5. Overview of the excavations at the Bowles Creek site. 
Four of the $1 \mathrm{x} 1 \mathrm{~m}$ units (Units 1-4) were placed to evaluate possible feature anomalies identified in the remote sensing work by McKinnon (2017, see Figure 3): Unit 1 (N119 W108) in the southernmost 20 x 20 m grid; Unit 2 (N119 W133) at the top of the south central part of the grid; and Unit 3 (N106 W138) and Unit 4 (N104 W130) in an area with an arch of possible post holes in the southern part of the south central grid square (Figure 6). These units had between 91-125 ancestral Caddo artifacts in the excavated archaeological deposits (see below). By comparison, Units 5 (N95 W124) and 6 (N94 W120), placed 5-6 $\mathrm{m}$ south of the remote sensing grid in areas with high densities of ceramic sherds and preserved plant and animal remains in previously excavated shovel tests (see Figure 4a-b), had between 144-241 artifacts per unit, and relatively high densities of preserved animal bone, especially in Unit 6 .

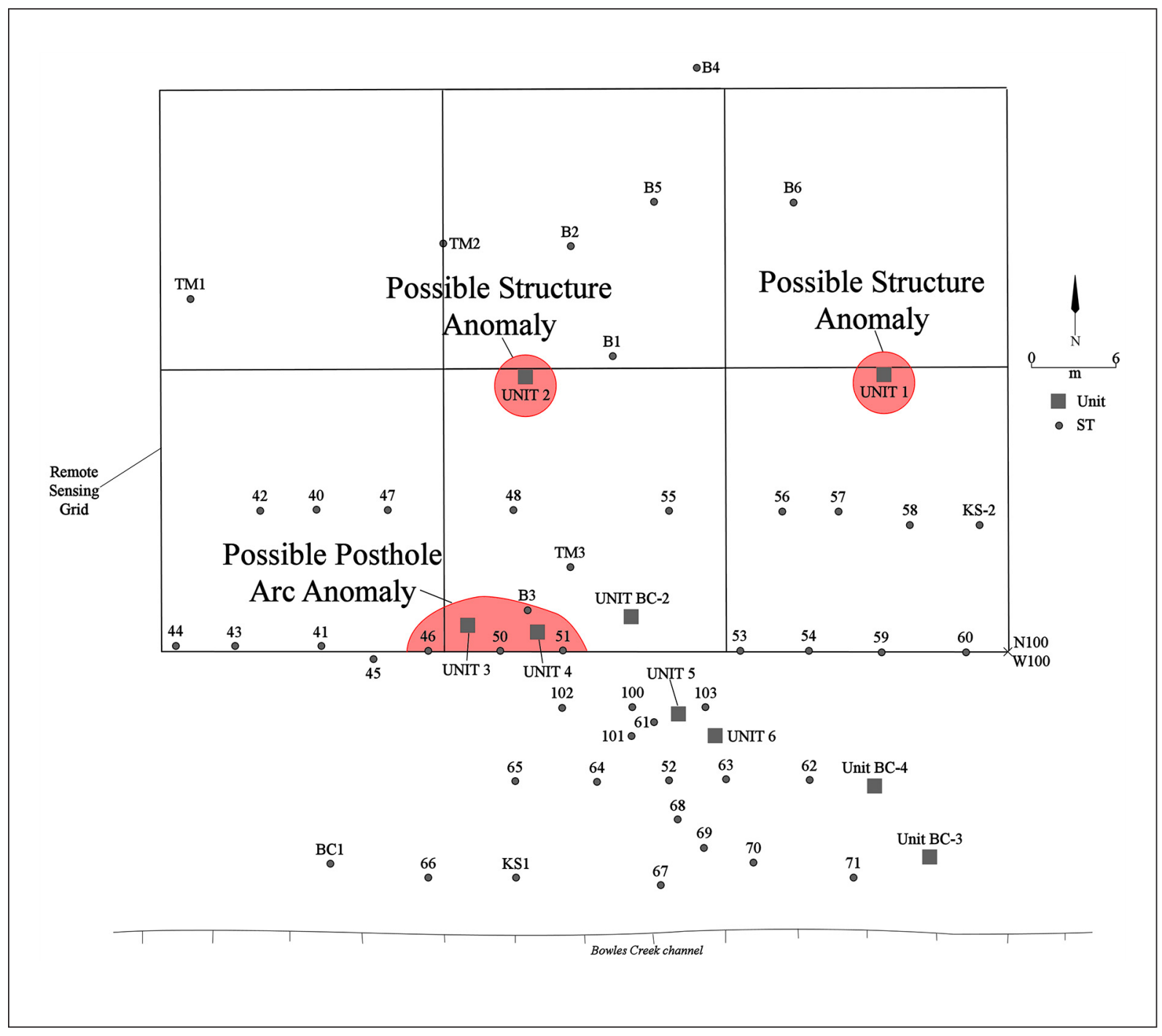

Figure 6. Location of Units 1-6 excavated by the East Texas Archeological Society at the Bowles Creek site. 


\section{Unit 1 (Figure 7)}

Unit 1 had reddish-brown sandy loam sediments from $0-50 \mathrm{~cm}$ bs; the clay B-horizon was not reached before the unit was terminated. A concentration of larger ceramic vessel sherds was encountered and mapped between 22-27 cm bs. Overall, the artifact density in Unit 1 was highest between 10-30 $\mathrm{cm}$ bs (Table 1), and about 90 percent of the recovered artifacts are plain and decorated ceramic vessel sherds. A Cuney arrow point was recovered between $10-20 \mathrm{~cm}$ bs.

Table 1. Material Culture Remains by depth in Unit 1.

\begin{tabular}{lllllllll}
\hline $\begin{array}{l}\text { Level } \\
\text { (cm bs) }\end{array}$ & PS & DS & LD & FCR & AP & WC & $\begin{array}{l}20^{\text {th }} \text { Century } \\
\text { Artifacts }\end{array}$ & N \\
\hline $0-10$ & 3 & 7 & - & - & - & - & - & 10 \\
$10-20$ & 8 & 20 & 2 & - & 1 & 2 & 2 & 35 \\
$20-30$ & 5 & 23 & - & - & - & - & - & 28 \\
$30-40$ & 2 & 13 & - & - & - & - & - & 5 \\
$40-50$ & 1 & 1 & - & 1 & - & 2 & - & 93 \\
\hline Totals & 19 & 64 & 2 & 1 & 1 & 4 & 2 & 5 \\
\hline
\end{tabular}

$\mathrm{PS}=$ plain sherd; $\mathrm{DS}=$ decorated sherd $\mathrm{LD}=$ lithic debris; $\mathrm{FCR}=$ fire-cracked rock; $\mathrm{AP}=$ arrow point; $\mathrm{WC}=$ wood charcoal

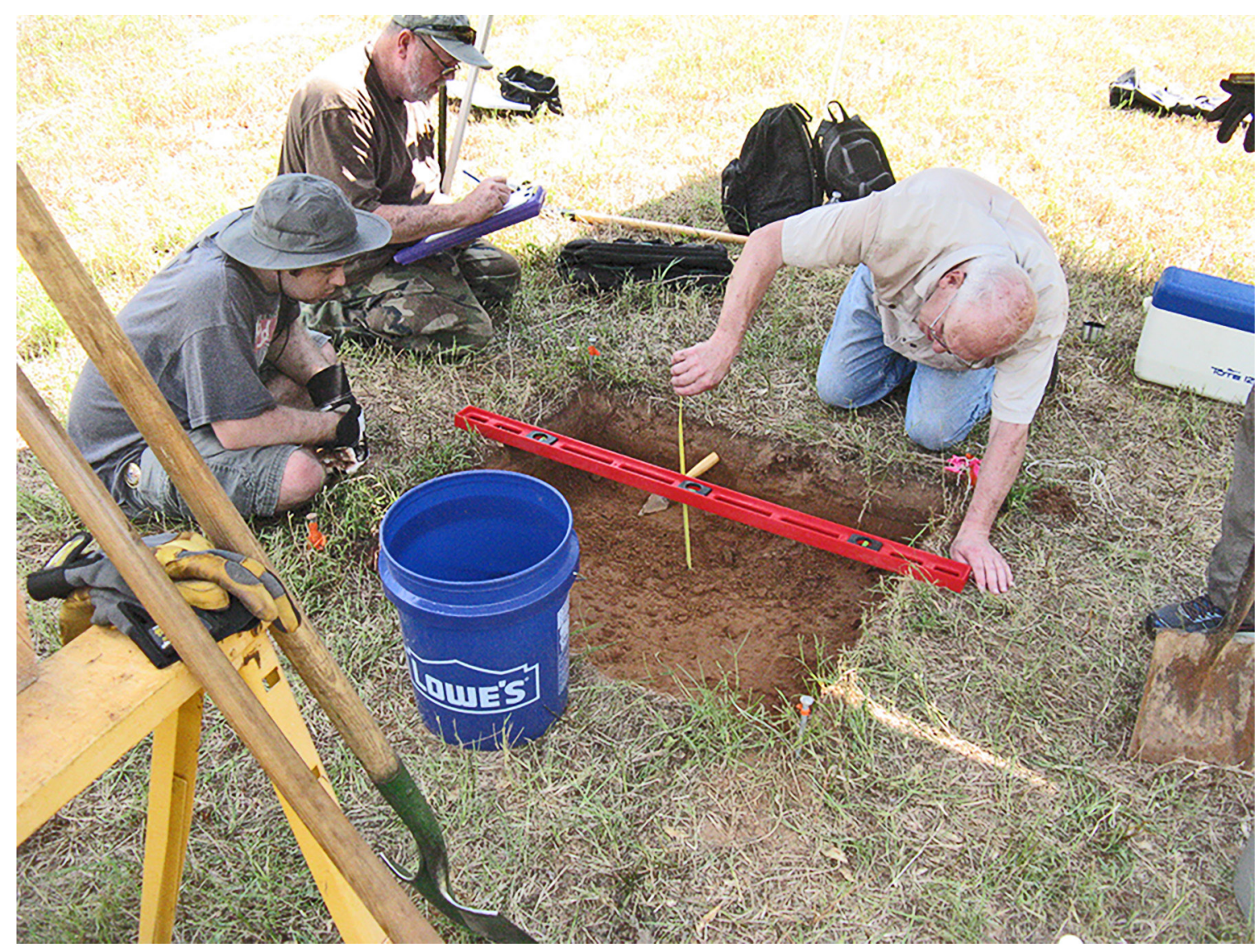

Figure 7. Unit 1, with Matthew DeWard, Bo Nelson (taking notes), and Jimmy Partin measuring an in situ ceramic vessel sherd. 


\section{Unit 2 (Figure 8)}

This unit had shallow reddish-brown sandy loam archaeological deposits that reached to only $30 \mathrm{~cm}$ bs; at that depth, the reddish-brown clay B-horizon was reached and no cultural features were apparent. The highest density of artifacts in the unit was between $10-20 \mathrm{~cm}$ bs (Table 2). About 90 percent of the recovered artifacts in the unit are ancestral Caddo ceramic vessel sherds.

Table 2. Material Culture Remains by depth in Unit 2.

\begin{tabular}{llllll}
\hline $\begin{array}{l}\text { Level } \\
(\mathrm{cm} \mathrm{bs})\end{array}$ & $\begin{array}{l}\text { Plain } \\
\text { Sherds }\end{array}$ & $\begin{array}{l}\text { Decorated } \\
\text { Sherds }\end{array}$ & Lithic Debris & $\begin{array}{l}20^{\text {th }} \text { Century } \\
\text { Artifacts }\end{array}$ & $\mathrm{N}$ \\
\hline $0-10$ & 4 & 13 & - & 2 & 19 \\
$10-20$ & 20 & 34 & 3 & - & 57 \\
$20-30$ & 4 & 12 & 5 & - & 21 \\
\hline Totals & 28 & 59 & 8 & 2 & 97 \\
\hline
\end{tabular}

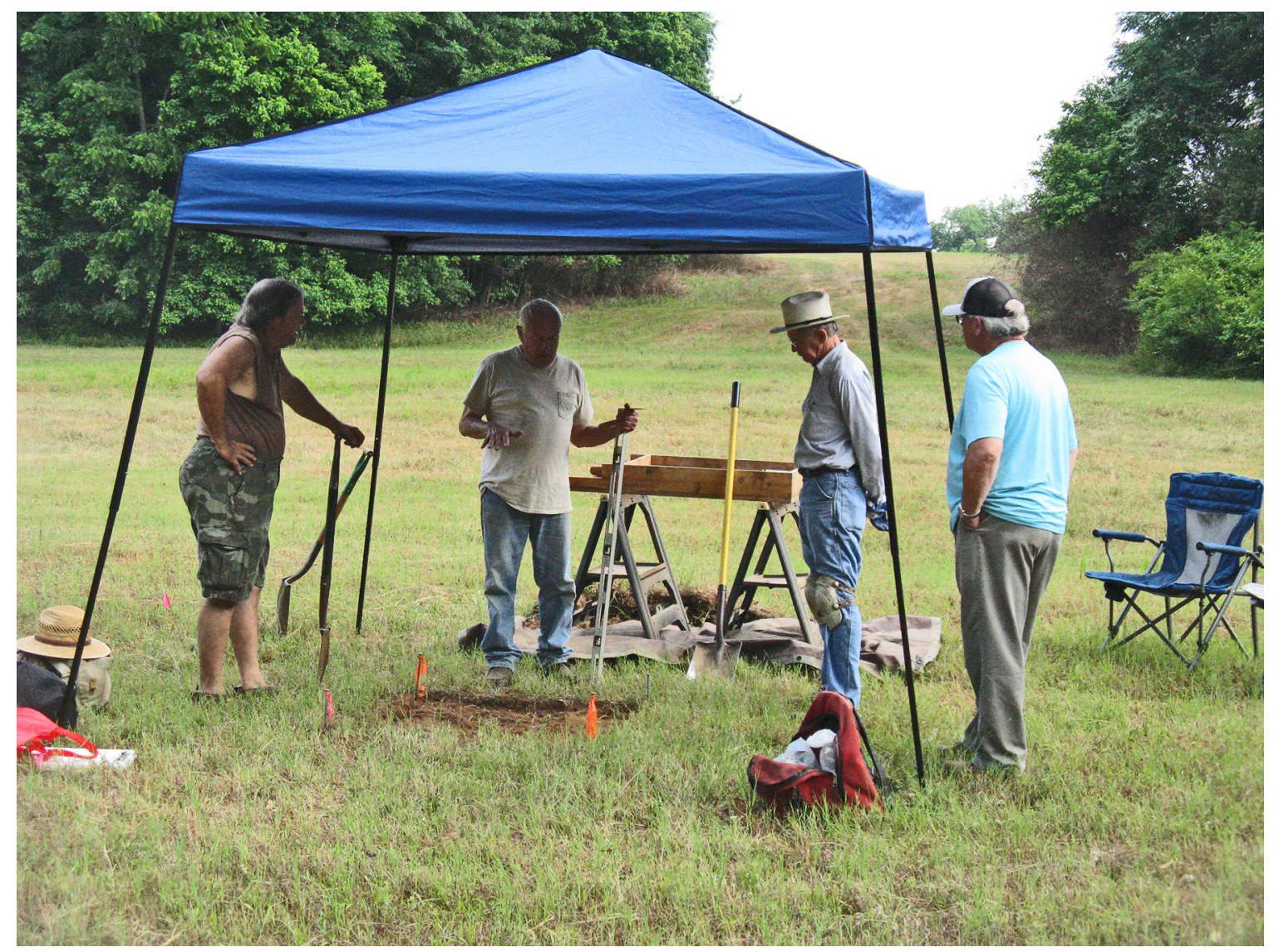

Figure 8. Unit 2, Mark Walters facing the camera and Lonnie Lindsey at the far right. 


\section{Unit 3 (Figure 9)}

This unit had sandy loam sediments to $50 \mathrm{~cm}$ bs, where the unit was terminated. The clay B-horizon had not been reached, and artifacts were still abundant in the lowest level (40-50 cm bs) (Table 3), and in the deposits from 20-40 cm bs; no features were noted in the excavations. About 93 percent of the recovered artifacts in Unit 3 are ancestral Caddo ceramic vessel sherds.

Table 3. Material Culture Remains by depth in Unit 3.

\begin{tabular}{llllllll}
\hline $\begin{array}{l}\text { Level } \\
\text { (cm bs })\end{array}$ & PS & DS & P & LD & WC & $\begin{array}{l}20^{\text {th }} \text { Century } \\
\text { Artifacts }\end{array}$ \\
\hline $0-10$ & 2 & 15 & - & 1 & - & 1 & N \\
$10-20$ & 3 & 7 & - & - & - & 1 & 11 \\
$20-30$ & 11 & 16 & - & - & - & - & 27 \\
$30-40$ & 11 & 16 & 1 & - & 2 & 1 & 28 \\
$40-50$ & 9 & 18 & - & - & 1 & - & 116 \\
\hline Totals & 36 & 72 & 1 & 1 & 3 & 3 & \\
\hline
\end{tabular}

PS=plain sherds; $\mathrm{DS}=$ decorated sherds; $\mathrm{P}=$ ceramic pipe sherd; $\mathrm{LD}=$ lithic debris; $\mathrm{WC}$-wood charcoal

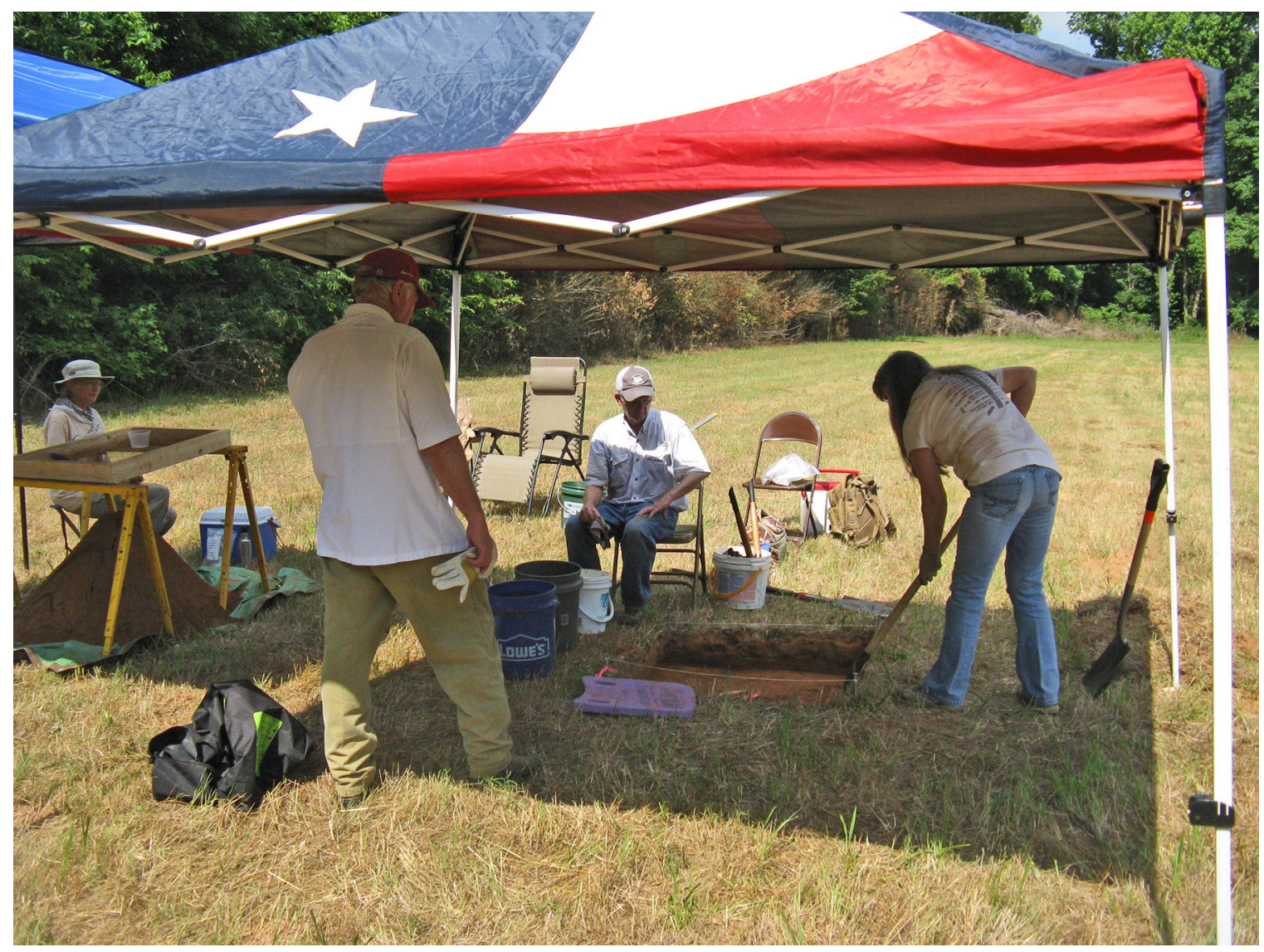

Figure 9, Unit 3, left to right: Ann Tindell, Winston Bolinger, Morris Jackson, and Pam Neeley. 


\section{Unit 4 (Figure 10)}

Unfortunately, not much information is available on the level form concerning the excavations of Unit 4, although it is presumed that the archaeological deposits here are in reddish-brown sandy loam sediments. The highest densities of artifacts in the unit are between $20-40 \mathrm{~cm}$ bs (Table 4). Almost 98 percent of the recovered artifacts in Unit 4 are ceramic vessel sherds.

\section{Table 4. Material Culture Remains by depth in Unit 4.}

\begin{tabular}{lllll}
\hline $\begin{array}{l}\text { Level } \\
(\mathrm{cm} \mathrm{bs})\end{array}$ & Plain Sherds & Decorated Sherds & Lithic Debris & N \\
\hline $0-10$ & 3 & 8 & - & 11 \\
$10-20$ & 9 & 13 & 1 & 23 \\
$20-30$ & 8 & 26 & - & 34 \\
$30-40$ & 15 & 21 & 1 & 37 \\
$40-50$ & 2 & 17 & 3 & 20 \\
\hline Totals & 37 & 85 & & 125 \\
\hline
\end{tabular}

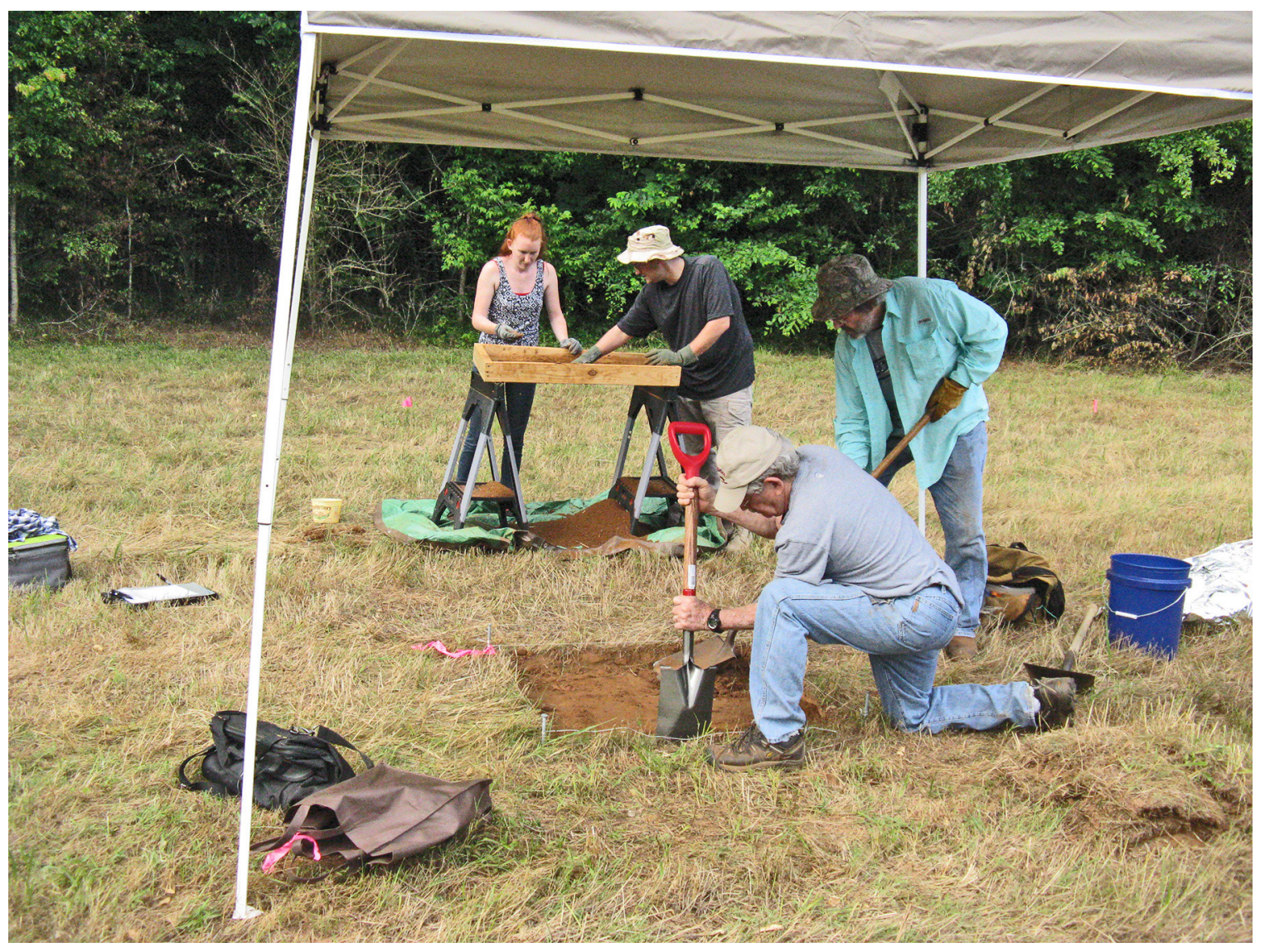

Figure 10. Unit 4, left to right: Kirsten Pounders, Edward Pounders, Tom Yarborough (kneeling), and Ron Coleman. 


\section{Unit 5 (Figure 11)}

Excavations in Unit 5 encountered possible midden deposits in levels 3 and 4, although the top of the midden deposits is not provided on the level form, and the base of the midden was not explored before the unit was terminated. Above the midden, the sediments are a dark reddish-brown sandy loam, while the midden is described as "darker," with charcoal. The highest densities of artifacts in Unit 5 are from $30-40 \mathrm{~cm}$ bs (Table 5). Animal bone is most abundant from 30-40 cm bs. Approximately 81 percent of the recovered artifacts in this unit are ancestral Caddo ceramic vessel sherds.

Table 5. Material Culture Remains by depth in Unit 5.

\begin{tabular}{llllllllll}
\hline $\begin{array}{l}\text { Level } \\
(\mathrm{cm} \mathrm{bs})\end{array}$ & PS & DS & P & D/BC & LD & T & WC & AB & N \\
\hline $0-10$ & 7 & 16 & 2 & $1 /-$ & - & - & - & 2 & 28 \\
$10-20$ & 13 & 17 & - & $-/ 2$ & 3 & - & - & 4 & 39 \\
$20-30$ & 13 & 16 & 1 & $-/-$ & 2 & - & - & - & 32 \\
$30-40$ & 5 & 29 & - & $-/-$ & 1 & 1 & 1 & 8 & 45 \\
\hline Totals & 38 & 79 & 3 & $1 / 2$ & 6 & 1 & 1 & 14 & 144 \\
\hline
\end{tabular}

$\mathrm{PS}=$ plain sherds; $\mathrm{DS}=$ decorated sherds; $\mathrm{P}=$ ceramic pipe sherds; $\mathrm{D}=$ daub; $\mathrm{BC}=$ burned clay; $\mathrm{LD}=$ lithic debris; T-tool; $\mathrm{WC}=$ wood charcoal; $\mathrm{AB}=$ animal bone

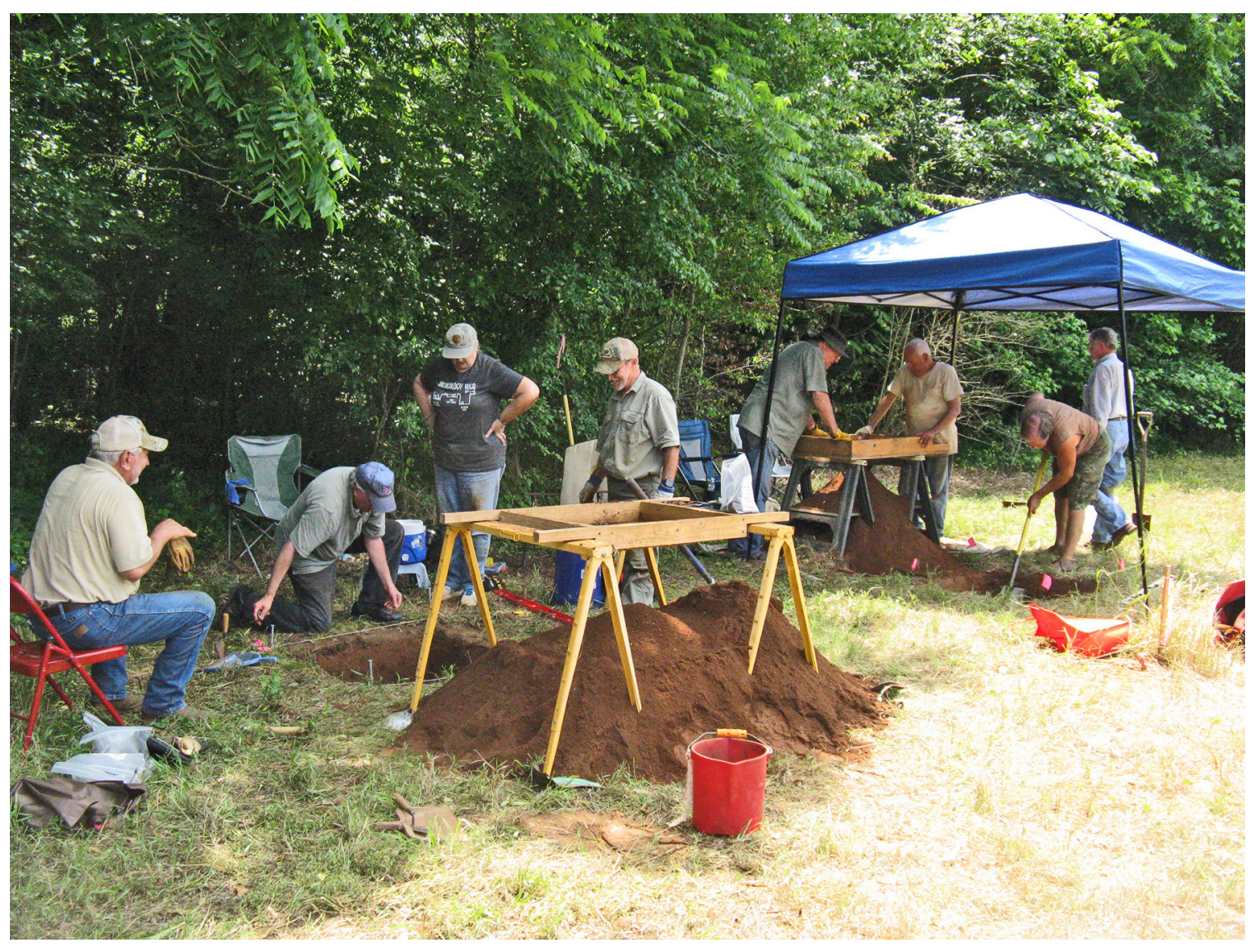

Figure 11. Units 5 and 6: Unit 6 crew on the left and Unit 5 on the right. 


\section{Unit 6 (Figure 12)}

No descriptions of the sediments in Unit 6 were provided on the level form, other than that a dark yellowish-brown loam was encountered at an unknown depth in level 5, along with pieces of charcoal. The density of artifacts in the unit is highest between $35-50 \mathrm{~cm}$ bs, particularly the number of burned and unburned animal bones and wood charcoal (Table 6); there may have been unrecognized midden deposits in this unit. About 59 percent of the recovered artifacts in Unit 6 are ceramic vessel sherds, and another 28 percent are animal bones.

Table 6. Material Culture Remains by depth in Unit 6.

\begin{tabular}{lllllllllll}
\hline $\begin{array}{l}\text { Level } \\
\text { (cm bs) }\end{array}$ & PS & DS & P & D/BC & LD & T & WC & AB & $\begin{array}{l}\text { 20th Cent. } \\
\text { Artifacts }\end{array}$ & N \\
\hline $0-10$ & 4 & 20 & 1 & $-/-$ & 1 & - & - & 1 & - & 27 \\
$10-25$ & 10 & 23 & - & $-/-$ & 4 & - & - & 4 & 5 & 46 \\
$25-35$ & 11 & 21 & - & $-/ 1$ & 1 & 1 & 1 & 9 & - & 45 \\
$35-40$ & 2 & 21 & - & $-/-$ & 6 & - & 10 & 30 & - & 69 \\
$40-50$ & 9 & 23 & 1 & $-/-$ & 2 & - & - & 24 & - & 59 \\
\hline Totals & 36 & 108 & 2 & $-/ 1$ & 14 & 1 & 11 & 68 & 5 & 246 \\
\hline
\end{tabular}

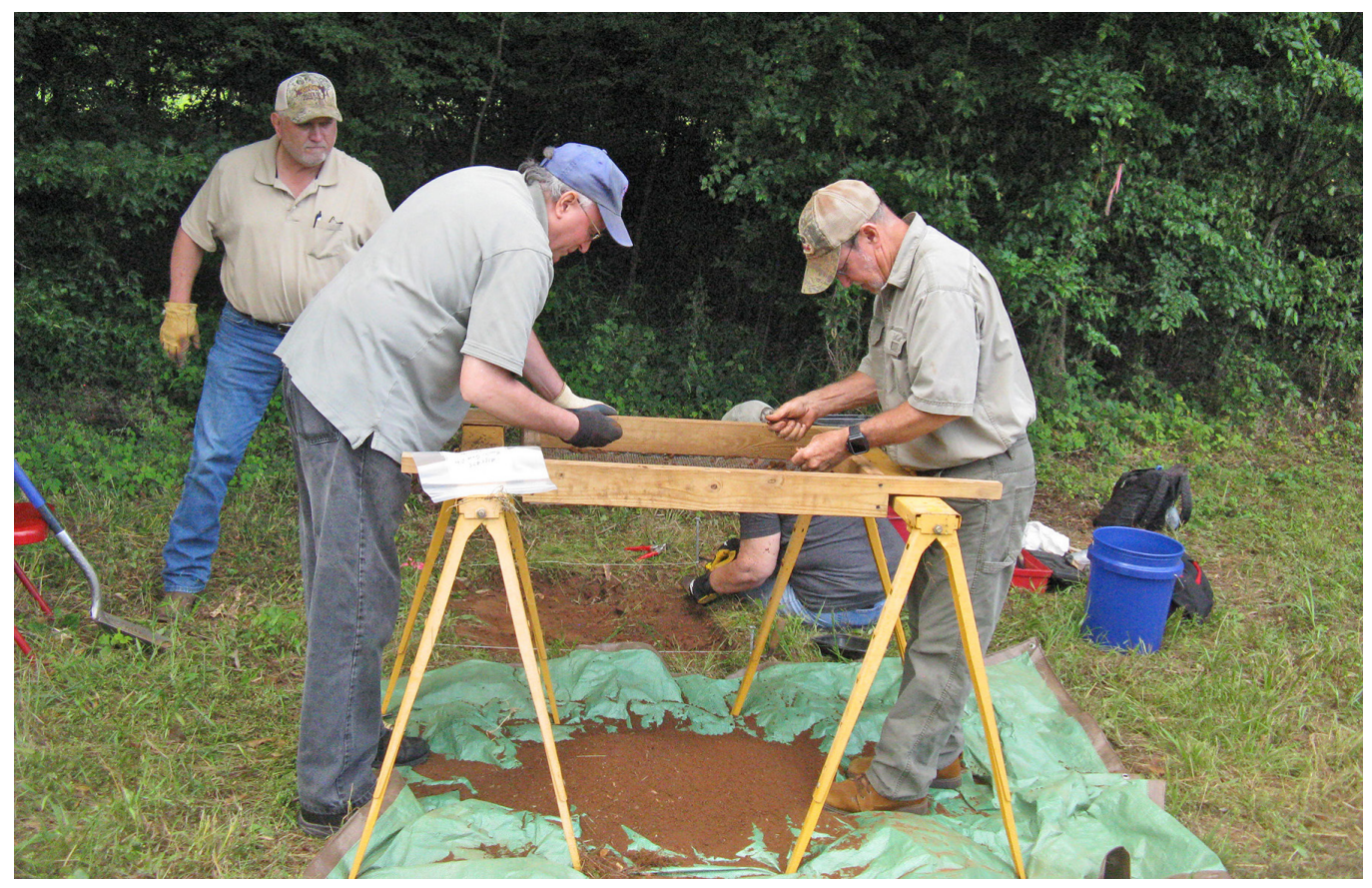

Figure 12. Unit 6, George Avery's crew.

\section{Archaeological Findings}

No cultural features were identified during the East Texas Archeological Society field work at the Bowles Creek site although Unit 5 appeared to have a midden deposit that began below $20 \mathrm{~cm}$ bs and extended to at least $40 \mathrm{~cm}$ bs; its bottom depth was not established as work in the unit was terminated at $40 \mathrm{~cm}$ bs. The absence of features in the $1 \times 1 \mathrm{~m}$ units excavated in the areas of several remote sensing 
anomalies was disappointing, but the findings from single $1 \times 1 \mathrm{~m}$ units in anomaly areas of more than 25 square meters (see Figure 3) are not sufficient to establish with confidence if the anomalies represent cultural features or not. Further work, perhaps as a trench of units that bisect the central and outer parts of the anomalies is needed in these areas to accomplish that.

\section{Material Culture Remains}

Including $20^{\text {th }}$ century historic artifacts from Units 1-3 and Unit $6(n=12)$, a total of 821 artifacts were recovered from archaeological deposits at the Bowles Creek site during the May 2018 East Texas Archeological Society field day (Table 7). Approximately 82 percent of the recovered artifacts are plain and decorated ceramic vessel sherds, followed by animal bones (10.1 percent, only in Units 5 and 6 ), lithic debris (4.2 percent), wood charcoal (2.4 percent), and ceramic pipe sherds ( 0.7 percent).

Table 7. Summary of ancestral Caddo material culture remains from Units 1-6.

\begin{tabular}{llllllllllll}
\hline Unit & PS & DS & P & D/BC & LD & FCR & AP & T & WC & AB & N \\
\hline 1 & 19 & 64 & - & $-/-$ & 2 & 1 & 1 & - & 4 & - & 91 \\
2 & 28 & 59 & - & $-/-$ & 8 & - & - & - & - & - & 95 \\
3 & 36 & 72 & 1 & $-/-$ & 1 & - & - & - & 3 & - & 113 \\
4 & 37 & 85 & - & $-/-$ & 3 & - & - & - & - & - & 125 \\
5 & 38 & 78 & 3 & $1 / 2$ & 5 & - & - & 1 & 1 & 14 & 144 \\
6 & 36 & 108 & 2 & $-/ 1$ & 14 & - & - & 1 & 11 & 68 & 240 \\
\hline Totals & 194 & 466 & 6 & $1 / 3$ & 34 & 1 & 1 & 2 & 19 & 82 & 809 \\
\hline
\end{tabular}

$\mathrm{PS}=$ plain sherds; $\mathrm{DS}=$ decorated sherds; $\mathrm{P}=$ ceramic pipe sherds; $\mathrm{D}=$ daub; $\mathrm{BC}=$ burned clay; $\mathrm{LD}=$ lithic debris; $\mathrm{FCR}=$ firecracked rock; $\mathrm{AP}=$ arrow point; $\mathrm{T}=$ tool; $\mathrm{WC}=$ wood charcoal; $\mathrm{AB}=$ animal bone

\section{Ceramic Vessel Sherds}

The ceramic vessel sherds from the latest work at the Bowles Creek site includes plain ware (29.4 percent of the assemblage and 27.6 percent of the rim sherds), utility ware (66.3 percent, and 58.6 percent of the rim sherds), and fine ware (4.4 percent, and 13.8 percent of the rim sherds) (Table 8 ). The low proportion of fine ware sherds is notable, but the rarity of engraved fine ware vessel sherds in the assemblage is consistent with previous analyses of the decorated sherd assemblage from the Bowles Creek site (see below).

Table 8. Plain, utility, and fine ware sherds from the 2018 East Texas Archeological Society field work at the Bowles Creek site.

\begin{tabular}{lllll}
\hline Sherd type & Plain ware & Utility ware & Fine ware & N \\
\hline Base & 20 & - & - & 20 \\
Body & 166 & 420 & 25 & 611 \\
Rim & 8 & 17 & 4 & 29 \\
\hline Totals & 194 & 437 & 29 & 660 \\
\hline
\end{tabular}


The ceramic wares in the 2018 ceramic sherd sample from the Bowles Creek site are from vessels tempered with combinations of grog (i.e., crushed sherds), burned bone, and crushed pieces of hematite (Table 9). Grog temper is present in between 92.8-96.6 percent of the vessel sherds, with the highest proportions among the fine wares and the lowest proportion among the plain ware sherds. Burned bone temper is present in comparable amounts in both the plain ware and utility ware (13.9-14.4 percent), but is conspiculously absent in the fine wares (Table 9).

Table 9. Temper groups by ware for sherds from the 2018 East Texas Archeological Society field work at the Bowles Creek site.

\begin{tabular}{|c|c|c|c|c|}
\hline Temper group & Plain ware & Utility ware & Fine ware & $\mathrm{N}$ \\
\hline bone & 3 & 6 & - & 9 \\
\hline bone-hematite & 9 & 15 & - & 24 \\
\hline grog & 97 & 242 & 16 & 355 \\
\hline grog-bone & 9 & 35 & - & 44 \\
\hline grog-bone-hematite & 6 & 12 & - & 18 \\
\hline grog-hematite & 68 & 125 & 12 & 205 \\
\hline hematite & 2 & 2 & 1 & 5 \\
\hline $\begin{array}{l}\text { \% with Grog } \\
94.2\end{array}$ & 92.8 & 94.7 & 96.6 & \\
\hline$\%$ with Bone & 13.9 & 14.4 & - & 14.4 \\
\hline$\%$ with Hematite & 44.8 & 35.3 & 44.8 & 38.2 \\
\hline Totals & 194 & 437 & 29 & 660 \\
\hline
\end{tabular}

Grog temper was added to the paste to hold the constituents of vessels together, but not limit the natural plasticity of the clays chosen for vessel manufacture; too much temper added to the paste, however, and the clay would be too limp to manipulate and shape, but too little temper, and a vessel would be likely to spall and break when it was being fired. The high frequency of grog tempering in this ceramic assemblage represents a specific attempt on the part of Caddo potters to slow the oxidation process of the ceramic vessels during firing. This would have created darker-colored vessels in a reducing firing environment (or lighter tan, orange, and brown colors in oxidizing environments), while allowing them to be fired longer, and producing a harder ceramic vessel (Rice 1987:354; Teltser 1993:532, 540). Since grog has expansion coefficients comparable to the coefficients of the clay paste most commonly seen in ancestral Caddo pottery vessels - especially with the finely crushed grog pieces in the fine wares - this would have contributed further to the ability of fired vessels to withstand heatrelated stresses, as well as increasing their flexural strength (Rice 1987:362). Gamble (2007:198) has also suggested that the addition of grog temper to pottery clay reflects more than simply a functional choice for potters. Instead, he interprets the temper choice as "the inclusion of the ancestors in the next generation of pots." Thus, every grog-tempered pot made by a Caddo potter can be construed as a link in an evolving ceramic tradition and a continued reinforcement of social identity.

The adding of crushed and burned bones to the paste of ceramic vessels may also have been an attempt (although only an occasional attempt) to give vessels the ability to withstand thermal shock. The angular particle shape of burned bone pieces gave the vessel paste a useful coarseness when it came to the firing of a bone-tempered vessel. 
The proportion of vessel sherds with hematite temper inclusions, almost always in association with grog, is notable in this assemblage (ranging between 35.3-44.8 percent by ware, with the highest proportions among the fine wares and plain wares) likely because hematite was not generally considered a temper in previous sherd analyses from the site, but simply a natural inclusion in the sandy paste of many of the vessel sherds. Further consideration, and a careful examination of the size and angularity of the hematite inclusions, indicates they have been crushed, then added to the paste. The practice of ancestral Caddo potters using hematite as a temper began in the Woodland period in the Neches River basin in East Texas. Robinson's (2017:28) petrographic analysis of sherds from the Early Caddo period George C. Davis site (41CE19) showed that one of the principal paste groups there (Paste Group C) is iron-tempered (i.e., ferrous hematite) as well as quartz and grog-tempered. Sherds in Paste Group C are from plain ware, incised, fingernail punctated, neck-banded, and punctated-incised utility wares, as well as fine ware vessels. The addition of hematite as a temper in some Caddo ceramic vessels in the upper Neches River basin may well have acted as a binding agent in some clays that would have better held the paste of a vessel together than a vessel without crushed hematite pieces as an additive (see Allain and Rigaud 1986:715; Wadley 2005). The addition of a coarse temper like hematite would have aided a vessel's ability to withstand thermal shock.

Chase Earles (September 2017 personal communication), a modern-day Caddo potter, indicates that hematite is used in producing ceramic vessels today because it "is used as a melter and a colorant in clay. So, it helps the clay sinter at a lower temperature (when mixed in naturally or as a powder) and as a colorant, either turning the clay body red or brown in oxidation." Earles also thinks that "iron rich or hematite clay was key to most Caddo pottery in that they fired in an open ground fire. In order for the pot to hold water it must fire at a lower temperature (1300 degrees F)."

The 466 decorated ceramic vessel sherds from the 2018 field work at the Bowles Creek site are dominated by utility wares ( 93.8 percent of the assemblage), particularly jars with brushed and brushedincised decorative elements (Table 10). These brushed and brushed-incised jar sherds are from Bullard Brushed (Figure 13a-c) and Spradley Brushed-Incised (Figure 13d-f) vessels. Rim and body sherds with brushed marks comprise 58.6 percent of the decorated sherds and 62.5 percent of the utility wares, while brushed-incised vessel sherds represent 23.2 percent of the decorated sherd assemblage and 24.7 percent of the utility wares. Nineteen (4.4 percent of the utility wares) of the brushed-incised sherds are from Spradley Brushed-Incised vessels that have parallel brushed marks and overlying diagonal, opposed, and parallel incised lines (Figure 13d-f). The brushed-incised-punctated $(n=1)$ and brushed-punctated $(n=7$, 1.6 percent of the utility ware sherd assemblage) sherds are probably from Maydelle Incised and Bullard Brushed vessels, particularly the sherds where there are punctated rows pushed through the brushing (Figure 13i; see also Suhm and Jelks 1962:21).

Table 10. Decorative methods and elements in the 2018 East Texas Archeological Society vessel sherd assemblage from the Bowles Creek site.

\begin{tabular}{llll}
\hline Decorative method and elements & Rim & Body & $\mathrm{N}$ \\
\hline
\end{tabular}

Utility Ware

Appliqued-Incised

appliqued node at lip-horizontal incised line

Brushed

diagonal brushed marks

horizontal brushed marks

horizontal-vertical brushed marks

opposed brushed marks
1

$-$

$\begin{array}{lll}3 & 2 & 5 \\ 4 & 3 & 7 \\ 1 & - & 1 \\ - & 10 & 10\end{array}$


Table 10. Decorative methods and elements in the 2018 East Texas Archeological Society vessel sherd assemblage from the Bowles Creek site, cont.

\begin{tabular}{|c|c|c|c|}
\hline Decorative method and elements & Rim & Body & $\mathrm{N}$ \\
\hline overlapping brushed marks & - & 4 & 4 \\
\hline parallel brushed marks & - & 245 & 245 \\
\hline vertical brushed marks & 1 & - & 1 \\
\hline \multicolumn{4}{|l|}{ Brushed-Incised } \\
\hline diagonal brushed marks-parallel incised lines & - & 1 & 1 \\
\hline horizontal brushed-incised marks and lines & - & 1 & 1 \\
\hline opposed brushed-incised marks and lines & - & 5 & 5 \\
\hline parallel brushed-incised marks and lines & - & 82 & 82 \\
\hline parallel brushed marks-overlying diagonal incised lines & - & 1 & 1 \\
\hline parallel brushed marks-overlying opposed incised lines & - & 3 & 3 \\
\hline parallel brushed marks-overlying parallel incised lines & - & 12 & 12 \\
\hline parallel brushed marks-overlying straight incised line & - & 3 & 3 \\
\hline \multicolumn{4}{|l|}{ Brushed-Incised-Punctated } \\
\hline $\begin{array}{l}\text { straight incised line-tool punctated row-diagonal } \\
\text { brushed marks }\end{array}$ & - & 1 & 1 \\
\hline \multicolumn{4}{|l|}{ Brushed-Punctated } \\
\hline $\begin{array}{l}\text { horizontal brushed marks-tool punctated row through } \\
\text { the brushed marks }\end{array}$ & 1 & - & 1 \\
\hline horizontal brushed marks-adjacent tool punctated row & - & 1 & 1 \\
\hline opposed brushed marks-tool punctated row & - & 1 & 1 \\
\hline parallel brushed marks-linear tool punctated row & - & 1 & 1 \\
\hline $\begin{array}{l}\text { parallel brushed marks-tool punctated row through the } \\
\text { brushed marks }\end{array}$ & - & 2 & 2 \\
\hline $\begin{array}{l}\text { parallel brushed marks-large tool punctation through } \\
\text { the brushed marks }\end{array}$ & - & 1 & 1 \\
\hline \multicolumn{4}{|l|}{ Grooved } \\
\hline horizontal grooves & 2 & - & 2 \\
\hline parallel grooves & - & 3 & 3 \\
\hline \multicolumn{4}{|l|}{ Grooved-Brushed } \\
\hline horizontal grooves-vertical brushed marks & - & 1 & 1 \\
\hline parallel grooves-parallel brushed marks & - & 1 & 1 \\
\hline \multicolumn{4}{|l|}{ Incised } \\
\hline diagonal incised lines & 1 & - & 1 \\
\hline diagonal opposed incised lines & - & 1 & 1 \\
\hline opposed incised lines & - & 3 & 3 \\
\hline parallel incised lines & - & 8 & 8 \\
\hline parallel incised lines, widely-spaced & - & 2 & 2 \\
\hline straight incised line & - & 10 & 10 \\
\hline \multicolumn{4}{|l|}{ Punctated } \\
\hline circular punctated row & - & 2 & 2 \\
\hline fingernail punctated row & - & 1 & 1 \\
\hline fingernail punctation, single & - & 1 & 1 \\
\hline
\end{tabular}


Table 10. Decorative methods and elements in the 2018 East Texas Archeological Society vessel sherd assemblage from the Bowles Creek site, cont.

\begin{tabular}{llll}
\hline Decorative method and elements & Rim & Body & N \\
\hline linear tool punctated row & - & 1 & 1 \\
tool punctated row beneath the lip & 3 & - & 4 \\
tool punctated row/rows & - & 4 & 3 \\
tool punctation, single & - & 3 & 1 \\
triangular tool punctated row & - & 1 &
\end{tabular}

\section{Fine Ware}

\section{Engraved}

concentric circular lines

curvilinear engraved line

curvilinear engraved line with tick marks

curvilinear engraved lines, one line with tick marks

horizontal engraved line

horizontal engraved line with tick marks

horizontal and curvilinear engraved lines

horizontal and curvilinear opposed engraved lines

horizontal and diagonal engraved lines; tick mark

on one of the diagonal lines

horizontal and vertical engraved lines

linear tick mark

opposed engraved lines

opposed curvilinear engraved lines

parallel engraved lines

straight engraved line with tick marks

triangular tick marks in row

\section{Engraved-Brushed}

horizontal engraved line above horizontal brushed

zone on body

\section{Engraved-Punctated}

horizontal-vertical engraved lines below a row

of tool punctations

\begin{tabular}{|c|c|c|}
\hline- & 1 & 1 \\
\hline- & 1 & 1 \\
\hline- & 1 & 1 \\
\hline - & 1 & 1 \\
\hline- & 1 & 1 \\
\hline 2 & 3 & 5 \\
\hline 1 & - & 1 \\
\hline- & 1 & 1 \\
\hline 1 & - & 1 \\
\hline- & 2 & 2 \\
\hline- & 1 & 1 \\
\hline - & 1 & 1 \\
\hline - & 1 & 1 \\
\hline - & 4 & 4 \\
\hline- & 2 & 2 \\
\hline- & 3 & 3 \\
\hline- & 1 & 1 \\
\hline 1 & - & 1 \\
\hline 21 & 445 & 466 \\
\hline
\end{tabular}

Totals

Another distinctive but uncommon Historic Caddo period ceramic type present at the Bowles Creek site Lindsey Grooved ( $n=7,1.6$ percent of the utility ware sherds in the assemblage). Lindsey Grooved is an Allen phase utility ware type comprised of large bowls or jars with direct or slightly everted rims. The rims have shallow horizontal grooves (see Figure 13g). Lindsey Grooved vessels also occur in conjunction with appliqued, brushed (see Figure 13h), incised, or punctated elements, typically either at the rim-body juncture or on the vessel body (see Perttula and Selden 2014).

The incised rim and body sherds in the 2018 Bowles Creek site ceramic assemblage comprise 5.7 percent of the utility wares (see Table 10). The sherds with diagonal incised lines, diagonal opposed 

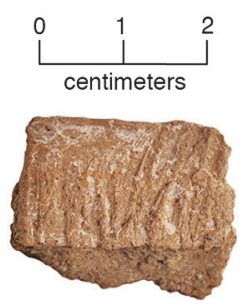

a

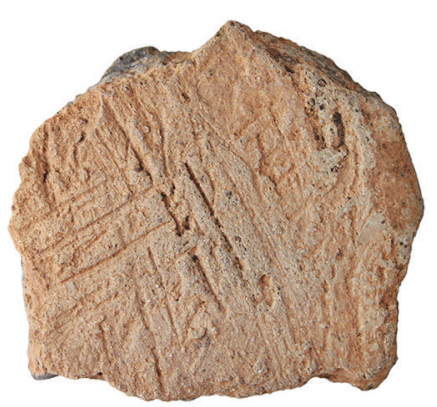

d

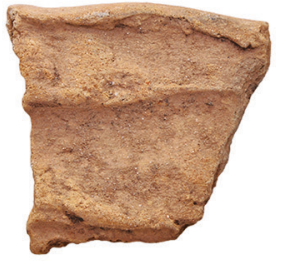

g

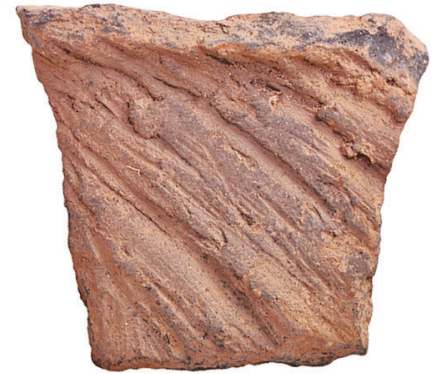

b
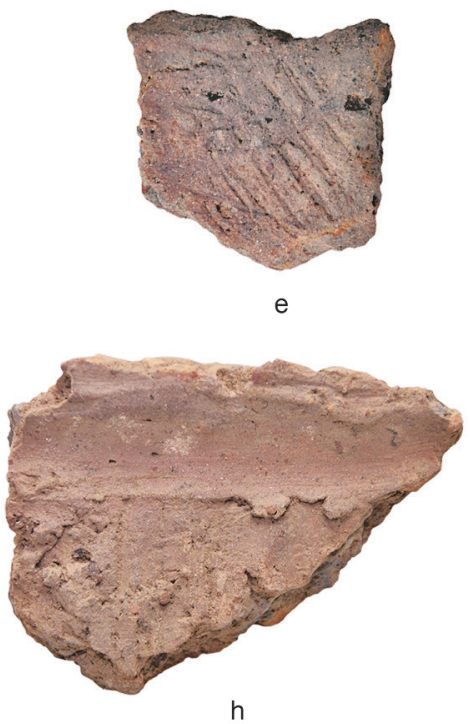
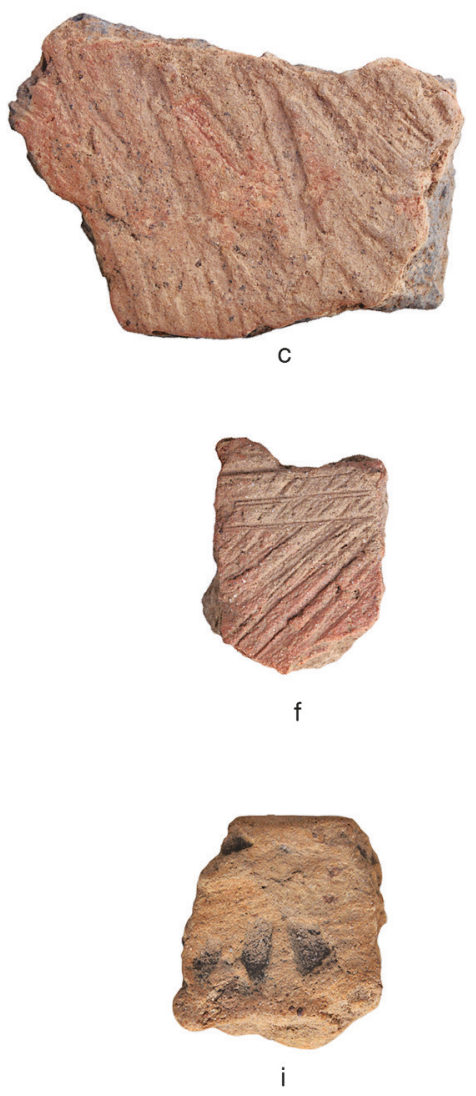

Figure 13. Selected utility ware sherds from the Bowles Creek site: a, vertical brushed rim, Unit 6, level 5; b, diagonal brushed body sherd, Unit 2, level 2; c, opposed brushed body sherd, Unit 4, level 2; d, Spradley Brushed-Incised body sherd, Unit 4, level 5; e, Spradley Brushed-Incised body sherd, Unit 1, level 1; f, Spradley Brushed-Incised body sherd, Unit 6, level 5; g, Lindsey Grooved rim sherd, Unit 5, level 4; h, Grooved-brushed rim and body sherd, Unit 5, level 4; i, brushed-punctated rim sherd, Unit 1, level 2.

incised lines (Figure 14), and opposed incised lines are from Maydelle Incised jars (see Suhm and Jelks 1962:103); the other incised sherds cannot be identified to a specific type, but it is likely that these are also from Maydelle Incised vessels.

About 3.7 percent of the utility wares have punctated elements, including circular, fingernail, linear tool, and tool punctations in rows on the vessel rim and/or the vessel body (see Table 10). Several rim sherds have a row of tool punctations beneath the lip, but the remainder of the rim decoration is unknown, and thus they are

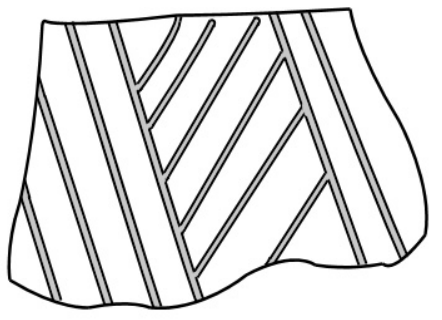

Figure 14. Maydelle Incised body sherd from Unit 3, level 5. unidentified to a defined East Texas ceramic type.

The fine ware sherds in the Bowles Creek site ceramic assemblage are from bowls and carinated bowls. They include sherds with engraved $(n=27,93.1$ percent of the fine ware assemblage), engraved-brushed $(n=1,3.4$ percent), and engraved-punctated $(n=1,3.4$ percent) elements (see Table 10). The principal fine ware type is Patton Engraved ( $\mathrm{n}=14$ sherds), and these have excised linear or triangular tick marks on curvilinear, horizontal, horizontal and diagonal, and straight engraved lines (Figures 15a-d and 16d, h). 
There is at least one Poynor Engraved sherd in the assemblage (see Figure 15e and Figure 16e). It has horizontal and curvilinear opposed engraved lines, and a red ochre-rich pigment has been rubbed in the engraved lines. Other distinctive engraved sherds have concentric circular lines (see Figure 15f and Figure 16f), opposed curvilinear engraved lines (see Figure 15g and Figure 16g), as well as curvilinear, horizontal and curvilinear, and horizontal and vertical engraved lines (see Table 10).
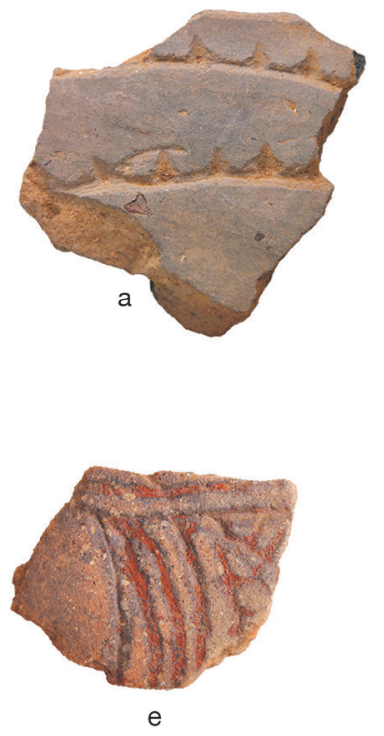

Figure 15. Selected fine ware sherds from the Bowles Creek site: a, Patton Engraved body sherd, Unit 6, level 5; b, Patton Engraved rim sherd, Unit 3, level 3; c, Patton Engraved body sherd, Unit 2, level 2; d, Patton Engraved body sherd, Unit 6, level 1; e, cf. Poynor Engraved body sherd, Unit 6, level 1; f, curvilinear engraved body sherd, Unit 2, level 2; g, curvilinear engraved body sherd, Unit 6, level 2; h, engraved-punctated body sherd, Unit 1 , level 5.

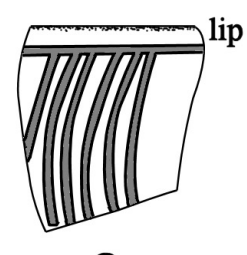

a
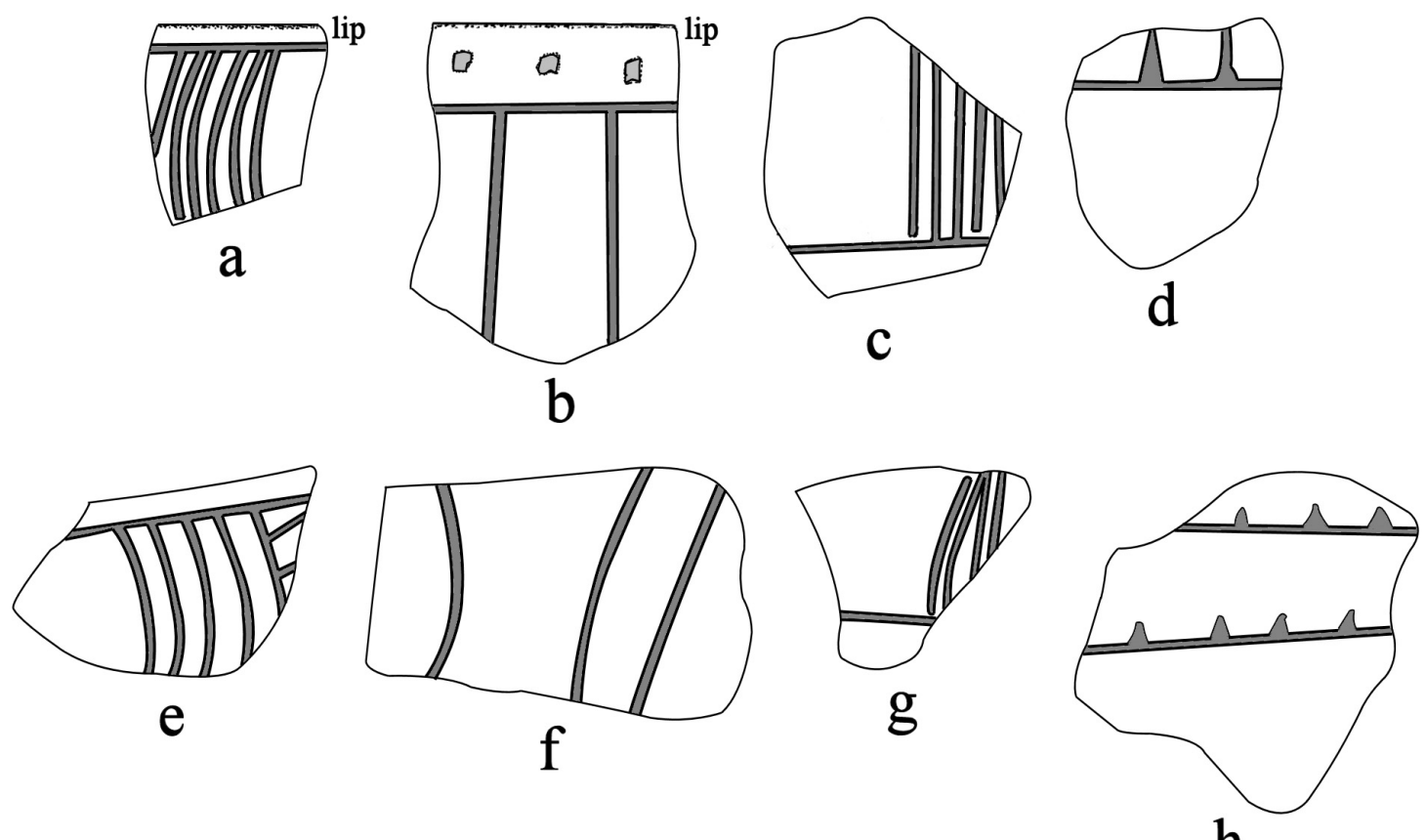

$\mathrm{h}$

Figure 16. Decorated elements on selected fine ware sherds from the Bowles Creek site: a, Unit 1, level 3; b, Unit 1, level 5; c, Unit 2, level 2; d, Unit 4, level 1; e, Unit 6, level 1; f, Unit 6, level 2; g, Unit 6, level 2; h, Unit 6, level 5. 
The one engraved-brushed sherd in the assemblage is from a carinated bowl. The lower part of the rim panel has a single horizontal engraved line, while the vessel body has horizontal brushed marks (see Table 10). Both Patton Engraved and Poynor Engraved carinated bowls sometimes have brushed bodies (see Suhm and Jelks 1962:117; Perttula 2011). The distinctive engraved-punctated rim sherd in the assemblage has a row of tool punctations beneath the lip as well as horizontal and vertical engraved lines on the rim (see Figure $15 \mathrm{~h}$ and $16 \mathrm{~b}$ ).

In summary, the ceramic assemblage from the Bowles Creek site from the various phases of work includes sherds primarily from grog-tempered vessels, but substantial numbers of sherds are from vessels tempered also with burned bone and hematite. The assemblage is dominated by decorated sherds from utility ware vessels, principally jars, and engraved fine wares are far from common (Table 11). The plain to decorated sherd ratio in the assemblage is a low 0.41 , and the brushed/plain ratio is 2.06 ; both index measures are consistent with the Neche ceramic cluster of the Historic Caddo Allen phase (see Perttula 2016).

Table 11. Summary of the ceramic sherd assemblage from the various phases of investigations at the Bowles Creek site (41CE475), including the 2018 East Texas Archeological Society work.

\begin{tabular}{|c|c|}
\hline Attribute & $\begin{array}{l}\text { Bowles Creek } \\
\text { Site }\end{array}$ \\
\hline No. of sherds & 2741 \\
\hline No. of decorated sherds & 1950 \\
\hline Plain ware & $791(28.9 \%)$ \\
\hline Utility ware & $1789(65.3 \%)$ \\
\hline Fine ware & $161(5.9 \%)$ \\
\hline $\mathrm{P} / \mathrm{DR}$ & 0.41 \\
\hline Brushed/Plain Ratio & 2.06 \\
\hline Grog-tempered & $90.7 \%$ \\
\hline Bone-tempered & $9.2 \%$ \\
\hline \multicolumn{2}{|l|}{ Utility Ware } \\
\hline Appliqued & $1(0.1 \%)$ \\
\hline Appliqued-Incised & $1(0.1 \%)$ \\
\hline Brushed & $1467(75.2 \%)$ \\
\hline Brushed-Appliqued & $3(0.2 \%)$ \\
\hline Brushed-Incised & $133(6.8 \%)$ \\
\hline Brushed-Incised-Punctated & $1(0.1 \%)$ \\
\hline Brushed-Punctated & $24(1.2 \%)$ \\
\hline Grooved & $14(0.7 \%)$ \\
\hline Grooved-Brushed & $2(0.1 \%)$ \\
\hline Incised & $87(4.5 \%)$ \\
\hline Incised-Punctated & $4(0.2 \%)$ \\
\hline Neck Banded & $4(0.2 \%)$ \\
\hline Notched & $1(0.1 \%)$ \\
\hline Pinched & $10(0.5 \%)$ \\
\hline Punctated & $43(2.2 \%)$ \\
\hline \multicolumn{2}{|l|}{ Fine Ware } \\
\hline Engraved & $146(7.5 \%)$ \\
\hline Engraved-Brushed & $4(0.2 \%)$ \\
\hline Engraved-Punctated & $4(0.2 \%)$ \\
\hline Trailed & $6(0.3 \%)$ \\
\hline
\end{tabular}

$\mathrm{P} / \mathrm{DR}=$ plain/decorated sherd ratio 
More than 75 percent of the decorated sherds from the site have brushed marks, and these sherds are likely from Bullard Brushed jars (see Suhm and Jelks 1962:Plate 11). Many of the brushed-incised and brushed-punctated sherds are also from Bullard Brushed jars, along with a number of sherds from Spradley Brushed-Incised vessels (see Perttula and Selden 2014:Figure 42). Grooved sherds from Lindsey Grooved vessels (see Perttula and Selden 2014:Figure 41) comprise only 0.8 percent of the decorated sherds from the Bowles Creek site, but this type is diagnostic of the Allen phase in the Neches/Angelina River basin in East Texas. Other utility wares in the assemblage include incised sherds from Maydelle Incised vessels (see Suhm and Jelks 1962:Plate 52), along with a few Killough Pinched sherds (see Suhm and Jelks 1962:Plate 46) and La Rue Neck Banded sherds (see Suhm and Jelks 1962:Plate 47).

The fine ware sherds in the Bowles Creek site ceramic assemblage are primarily represented by sherds from several varieties of Patton Engraved, including var. Allen and var. Patton (see Perttula 2011:Figure 6-66a-b). Approximately 0.4 percent of the fine ware sherds have engraved-brushed or engraved-punctated elements, the former on carinated bowls with brushed bodies and engraved rim panels. There are a few sherds from Poynor Engraved vessels and Keno Trailed vessels.

\section{Ceramic Elbow Pipe Sherds}

Six ceramic elbow pipe sherds were recovered in Unit 3, Unit 5, and Unit 6 at the Bowles Creek site. They include one engraved bowl rim sherd (Figure 17a), two stem sherds with horizontal engraved or incised lines (Figure 17e-f), and three plain bowl rim sherds (Figure 17b-d).

The engraved grog-tempered elbow pipe rim sherd has a zone of closely-spaced horizontal engraved lines (see Figure 17a). The rim is $6.2 \mathrm{~mm}$ thick. Similar engraved elbow pipes from Historic Caddo Allen phase contexts include a pipe bowl from 41HO64 (Perttula et al. 2004:Figure 12) on San Pedro Creek and another from the Deshazo site (41NA27) (Napoleon 1995:Figure 53e).

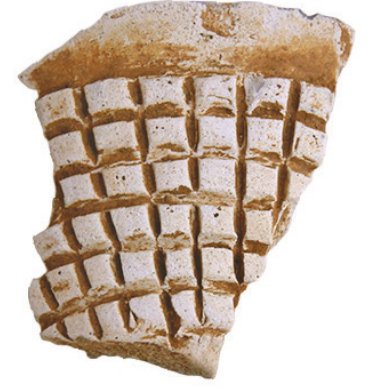

a

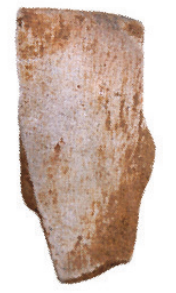

d

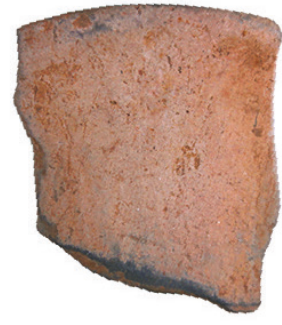

b
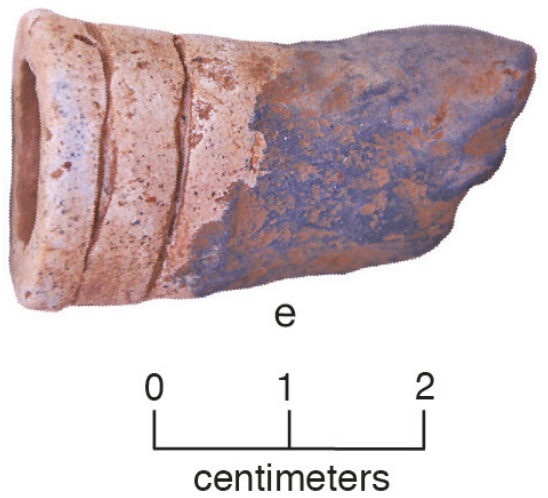
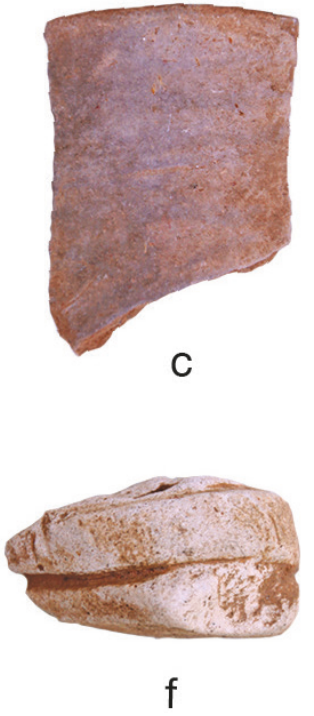

?

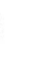


Two other elbow pipe stem sherds have two engraved or incised lines (see Figure 17e-f). These are comparable to Var. B elbow pipes defined in Late and Historic Caddo sites in the upper Neches River basin (Perttula 2011:215 and Figure 6-23). The elbow pipe stem sherd with the engraved lines is tempered with grog and hematite, has an exterior diameter of $21.9 \mathrm{~mm}$, an interior diameter of $13.0 \mathrm{~mm}$, and is $4.3 \mathrm{~mm}$ thick, while the other (from Unit 3, 30-40 cm bs) is tempered with grog.

The remaining elbow pipe sherds are plain bowl sherds (see Figure 17b-d). The Unit 5 (20-30 cm bs) plain pipe bowl sherd is grog-tempered and $3.2 \mathrm{~mm}$ thick (see Figure 17d). Both plain elbow pipe bowl rim sherds from Unit 6 are from grog-tempered pipes (see Figure 17b-c), and they range from 3.8-4.8 $\mathrm{mm}$ in wall thickness.

\section{Daub and Burned Clay}

Daub and burned clay pieces are sparse in the archaeological deposits at the site (see Table 7), indicating that either structures at the site were not covered with clay as part of the walls, or that none of the structures at the site had burned and therefore not preserving the clay as daub or burned clay. The one piece of daub is from Unit $5(0-10 \mathrm{~cm}$ bs $)$, while the burned clay came from Unit $5(10-20 \mathrm{~cm} \mathrm{bs})$ and Unit $6(25-35 \mathrm{~cm} \mathrm{bs})$.

\section{Cuney Arrow Point}

The Cuney arrow point (see Turner et al. 2011:187) from Unit $1(10-20 \mathrm{~cm}$ bs) is bifacially flaked from a piece of non-local gray chert (Figure 18). The point is $30.0 \mathrm{~mm}$ in length, $14.1 \mathrm{~mm}$ in width, 2.5 $\mathrm{mm}$ thick, and has a $4.3 \mathrm{~mm}$ stem width.
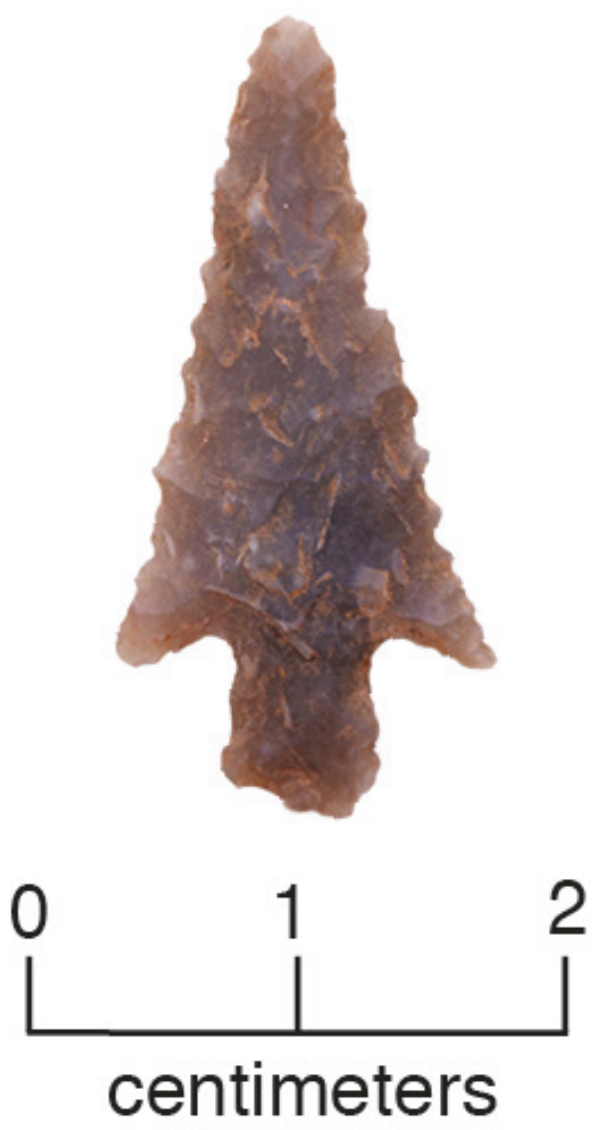

Figure 18. Cuney arrow point from the Bowles Creek Site, Unit 1, level 2. 
Cuney arrow points occur almost exclusively on Historic Caddo sites in the Neches and Angelina river basins (Perttula and Marceaux 2018:Table 8). But they are not very common (ca. 6.7 percent of 260 points from 17 Historic Caddo assemblages in the Neches and Angelina River basins) compared to Perdiz and Turney arrow points in these assemblages.

\section{Other Lithic Tools}

There are two other lithic tools in the 2018 artifact assemblage from the Bowles Creek site (see Table 7). They include a fragment of a unifacial scraper in Unit $5(30-40 \mathrm{~cm} \mathrm{bs})$ made on a non-local translucent gray chert and a ferruginous sandstone pitted stone fragment in Unit 6 (25-35 cm bs).

\section{Lithic Debris}

Evidence of lithic knapping and chipped stone tool manufacture at the Bowles Creek site by ancestral Caddo peoples in Historic Caddo period times is far from abundant. A total of only 34 pieces of lithic debris was recovered from Units 1-6, a mean of 5.7 pieces of lithic debris per square meter of archaeological deposits; most of the lithic debris is from Unit $6(n=14,41$ percent of the assemblage) and Unit 2 ( $n=8,23.5$ percent). Chipped stone manufacture was apparently not a common activity during the Historic Caddo occupation.

The lithic debris is divided equally between raw materials of local origin (likely mainly in gravel sources - petrified wood and quartzite) - and raw materials of non-local origin, including cherts of different colors (Table 12). Of the latter, gray chert and dark gray chert raw materials are most abundant. It is likely that most of these cherts originated in the Edwards Formation of Central Texas, and these pieces of lithic debris were removed from finished tools as they were resharpened and re-used. One of the pieces of chert lithic debris has a smoothed limestone cortex.

Table 12. Lithic debris from the 2018 East Texas Archeological Society work at the Bowles Creek site.

\begin{tabular}{lllll}
\hline Raw Material & NC & C-SM & C-R & N \\
\hline $\begin{array}{l}\text { Probable Non-Local } \\
\text { black chert }\end{array}$ & 1 & & & 1 \\
dark gray chert & 2 & - & - & 5 \\
light gray chert & 3 & - & - & 3 \\
gray chert & 4 & - & - & 5 \\
grayish-yellow chert & 1 & - & - & 2 \\
very dark gray chert & 2 & 6 & 2 & 14 \\
$\begin{array}{l}\text { Local } \\
\text { petrified wood }\end{array}$ & 6 & - & - & 3 \\
quartzite & 3 & 9 & 3 & 34 \\
\hline Totals & 23 & & & \\
\hline
\end{tabular}

$\mathrm{NC}=$ non-cortical; $\mathrm{C}-\mathrm{SM}=$ cortical and stream-rolled; $\mathrm{C}-\mathrm{R}=$ cortical and roughened surface

*limestone cortex

More than 82 percent of the lithic debris on local raw materials is petrified wood (see Table 12). Approximately 57 percent of the petrified wood lithic debris has cortical surfaces, either smoothed and stream-rolled or roughened, and probably obtained from a bedrock outcrop. 


\section{Fire-cracked Rock}

Only a single piece of ferruginous sandstone fire-cracked rock was recovered in the work at the Bowles Creek site. This was found in Unit 1 between $40-50 \mathrm{~cm}$ bs.

\section{Wood Charcoal}

A total of 19 pieces of wood charcoal were recovered in the screening of the archaeological deposits through 1/4-inch mesh. About 58 percent of the wood charcoal is from Unit 6, primarily from $35-40 \mathrm{~cm}$ bs (see Table 6). None of the wood charcoal has been examined to date by a paleobotanist.

\section{Animal Bones}

All of the recovered animal bone came from Unit $5(n=14)$ and Unit $6(n=68)$, units placed south of the remote sensing grid and in areas known to have preserved animal bones in the archaeological deposits (see Figure 14b). The bones include both burned $(n=55)$ and unburned $(n=27)$ pieces. The animal bones have not yet been examined by a faunal analyst.

\section{$20^{\text {th }}$ Century Historic Artifacts}

Twelve $20^{\text {th }}$ century artifacts were recovered in Units 1-3 and Unit 5 at the Bowles Creek site (see Table 7). These include five pieces of clear machine-made bottle glass (Unit 1, 10-20 cm bs, Unit 2, 0-10 $\mathrm{cm}$ bs, and Unit 6, 10-25 cm bs), three iron fence staples (Unit 3, 0-10 cm bs and Unit 6, 10-25 cm bs), and post- 1890 wire nails ( $\mathrm{n}=4$, Unit 3, 10-20 cm bs, Unit 3, 30-40 cm bs, Unit 6, 10-25 cm bs). Almost all of these artifacts are from the plow zones in the various units.

\section{Summary and Conclusions}

In May 2018, members of the East Texas Archeological Society (ETAS) led by Dr. Tom Middlebrook conducted a Field Day of excavations at the Bowles Creek site (41CE475), in the Bowles Creek valley of the Neches River basin, in Cherokee County, Texas. Previous investigations at the Bowles Creek site by Kevin Stingley and remote sensing work by Dr. Duncan P. McKinnon have shown that the site is an Historic Caddo period Allen phase settlement dating from ca. A.D. 1680 to possibly the early $18^{\text {th }}$ century with structural features and midden deposits.

The ETAS work consisted of the excavation of $61 \times 1 \mathrm{~m}$ units (Units 1-6) to a maximum depth of 50 $\mathrm{cm}$ bs in reddish-brown sandy loam sediments; only one unit (Unit 2) reached the sterile B-horizon clay, while the excavations in the others sampled the uppermost Historic Caddo archaeological deposits. Units 1-4 were placed by the ETAS to evaluate in a preliminary way the anomalies identified by McKinnon (2017) that may be possible structural features or an arc of possible post holes. Units 5 and 6 were placed south of the remote sensing grid in an area where higher densities of ceramic vessel sherds, animal bones, charred plant remains, and likely features had been recognized in previous shovel testing. Unit 5 encountered midden deposits of unknown thickness, and both Unit 5 and Unit 6 had higher densities of material culture remains that did Units 1-4, but no other cultural features were recognized in the remaining ETAS units.

The material culture remains recovered in the ETAS work was dominated by ceramic vessel sherds from Historic Caddo Allen phase grog-tempered, grog-hematite-tempered, and grog-bone-tempered vessels, particularly from brushed and brushed-incised Bullard Brushed and Spradley Brushed-Incised 
jars. Other utility ware types identified in this assemblage are Lindsey Grooved and Maydelle Incised. Fine ware sherds, although not common in the decorated sherds (6.2 percent) in the assemblage, primarily are from Patton Engraved vessels, another Allen phase diagnostic ceramic type.

Other distinctive artifacts recovered in the ETAS work include six elbow pipe sherds, including one bowl sherd decorated with a cross-hatched engraved zone and two other stem sherds with horizontal engraved or incised lines at the heel, of at least two different kinds of elbow pipes. One Cuney arrow point was recovered in Unit 1; this type is found on Historic Caddo Allen phase sites in the Neches/ Angelina River basins in East Texas. The remainder of the artifacts associated with the Allen phase settlement of the Bowles Creek site include a chert scraper fragment, a ferruginous sandstone pitted stone fragment, a small amount of lithic debris from both local (petrified wood and quartzite) and non-local (cherts of various colors) raw material sources, as well as wood charcoal, and burned and unburned animal bones. The latter came almost exclusively from Units 5 and 6 at the southern end of the site, where there are midden deposits preserved.

\section{Acknowledgments}

Thanks to Tom Middlebrook and the rest of the East Texas Archeological Society members for their hard work at the Bowles Creek site. All of the crew is grateful to the landowner, Lonnie Lindsey, for permission to work at the site, and for providing an excellent barbecue lunch. Figures in this article were prepared by Lance Trask, Brian Wootan, Duncan McKinnon, and Kevin Stingley.

\section{References Cited}

Allain, J. and A. Rigaud

1986 Décor et function: quelques exemles tires du Magdalenien. L'Anthropologie 90:713-738.

Cole, N. M.

1975 Early Historic Caddoan Mortuary Practices in the Upper Neches Drainage, East Texas. Master's thesis, Department of Anthropology, The University of Texas at Austin.

Fields, R. C. and J. P. Thurmond

1980 The George C. Davis Site, Cherokee County, Texas: Spring 1980 Archeological Investigations. Report of Investigations No. 8. Prewitt and Associates, Inc., Austin.

Gamble, C.

2007 Origins and Revolutions: Human Identity in Earliest Prehistory. Cambridge University Press, Cambridge.

Jackson, M. K., T. Middlebrook, G. Avery, H. Shafer, and B. Meissner

2012 Trade and Cultural Interaction along El Camino Real de los Tejas During the Spanish Colonial and Republic Periods in Nacogdoches County, Texas. 2 Vols. Nine Flags Museum, Nacogdoches.

Kenmotsu, N. A

1992 The Mayhew Site: A Possible Hasinai Farmstead, Nacogdoches County, Texas. Bulletin of the Texas Archeological Society 63:135-174.

Marceaux, P. S.

2011 The Archaeology and Ethnohistory of the Hasinai Caddo: Material Culture and the Course of European Contact. Ph.D. dissertation, Department of Anthropology, The University of Texas at Austin.

McKinnon, D. P.

2017 Report on Magnetic Gradient Survey at Three Caddo Sites in East Texas. Journal of Northeast Texas Archaeology 72:169-175. 
Napoleon, P. N.

1995 Analysis of Native-Made Pipes. In The Deshazo Site, Nacogdoches County, Texas, Vol. 2: Artifacts of Native Manufacture, edited by D. A. Story, pp. 157-171. Studies in Archeology 21. Texas Archeological Research Laboratory, The University of Texas at Austin.

Perttula, T. K.

2011 The Ceramic Artifacts from the Lang Pasture Site (41AN38) and the Place of the Site within an Upper Neches River Basin Caddo Ceramic Tradition. In Archeological Investigations at the Lang Pasture Site (41AN38) in the Upper Neches River Basin of East Texas, assembled and edited by T. K. Perttula, D. B. Kelley, and R. A. Ricklis, pp. 145-320. Archeological Studies Program Report No. 129, Texas Department of Transportation, Environmental Affairs Division, Austin.

2016 Utility Ware Ceramic Metrics and Hasinai Caddo Archaeology in East Texas. Journal of Northeast Texas Archaeology 70:61-68.

Perttula, T. K. and P. Marceaux

2018 The Lithic and Ceramic Artifacts from the Spradley Site (41NA206), Nacogdoches County, Texas. Special Publication No. 50. Friends of Northeast Texas Archaeology, Pittsburg and Austin.

Perttula, T. K. and R. Z. Selden, Jr.

2014 Ancestral Caddo Ceramics in East Texas. Journal of Northeast Texas Archaeology 48:9-58.

Perttula, T. K. and K. Stingley

2016a Additional Material Culture Remains from the Bowles Creek Site (41CE475) in Cherokee County, Texas. Journal of Northeast Texas Archaeology 67:7-14.

2016b Analysis of the Recovered Artifacts from the Controlled Surface Collection at the Peach Orchard Site (41CE477), Cherokee County, Texas. Journal of Northeast Texas Archaeology 70:91-110.

2017a Renewed Archaeological Investigations at the Bowles Creek (41CE475), Cornfield (41CE476), and Peach Orchard (41CE477) Sites in the Bowles Creek Valley, Cherokee County, Texas. Journal of Northeast Texas Archaeology 71 (2017):1-21.

2017b Continued Shovel Test Investigations at the Historic Caddo Allen Phase Bowles Creek Site (41CE475), Cherokee County, Texas. Journal of Northeast Texas Archaeology 71:105-122.

2017c Test Excavations and Additional Surface Collections at the Peach Orchard Site (41CE477) on Bowles Creek in Cherokee County, Texas. Journal of Northeast Texas Archaeology 73:81-93.

2017d Archaeological Investigations at the Mike Myers Site (41CE481) on Bowles Creek in Cherokee County, Texas. Journal of Northeast Texas Archaeology 74:47-80.

Perttula, T. K., L. L. Bush, L. Schniebs, T. Middlebrook, and P. S. Marceaux

2010 An Early Historic Caddo Farmstead at the Henry M. Site (41NA60) in Nacogdoches County, Texas. Stephen F. Austin State University Press, Nacogdoches.

Perttula, T. K., T. E. Emerson, and R. E. Hughes

200441 HO64/41HO65, Late $17^{\text {th }}$ to Early $18^{\text {th }}$ Century Caddo Sites on San Pedro Creek in Houston County, Texas. Bulletin of the Texas Archeological Society 75:85-103.

Perttula, T. K., K. Stingley, and M. Walters

2016 Historic Caddo Archaeological Sites in Cherokee County, Texas. Journal of Northeast Texas Archaeology 65:1-24.

2017 Archaeological Investigations at the Bowles Creek Site (41CE475), Cherokee County, Texas, in Early 2017. Journal of Northeast Texas Archaeology 74:85-95. 
Prewitt, E. R.

2018 Bayou Loco: Investigations and Speculations. Journal of Northeast Texas Archaeology 80, in press.

Rice, P. M.

1987 Pottery Analysis: A Sourcebook. University of Chicago Press, Chicago.

Robinson, D. G.

2017 Ceramic Petrographic Analysis of Prehistoric Pottery from the George C. Davis Site (41CE19), Cherokee County, Texas. In Specialized Ceramic Analyses of the George C. Davis Site (41CE19) Ceramic Assemblage, Cherokee County, Texas, assembled by T. K. Perttula, pp. 13-52. Report of Investigations No. 146. Archeological \& Environmental Consultants, LLC, Austin.

Stingley, K. and T. K. Perttula

2017 The Garden Site (41CE480) on Bowles Creek, Cherokee County, Texas. Journal of Northeast Texas Archaeology 71:55-60.

Story, D. A. (editor)

1982 The Deshazo Site, Nacogdoches County, Texas, Vol. 1: The Site, Its Setting, Investigations, Cultural Features, Artifacts of Non-Native Manufacture, and Subsistence Remains. Texas Antiquities Permit Series No. 7. Texas Antiquities Committee, Austin.

1995 The Deshazo Site, Nacogdoches County, Texas, Vol. 2: Artifacts of Native Manufacture. Studies in Archeology 21. Texas Archeological Research Laboratory, The University of Texas at Austin.

Suhm, D. A. and E. B. Jelks (editors)

1962 Handbook of Texas Archeology: Type Descriptions. Special Publication No. 1, Texas Archeological Society and Bulletin No. 4, Texas Memorial Museum, Austin.

Teltser, P. A.

1993 An Analytic Strategy for Studying Assemblage-Scale Ceramic Variation: A Case Study from Southeast Missouri. American Antiquity 58(3):530-543.

Turner, E. S., T. R. Hester, and R. L. McReynolds

2011 Stone Artifacts of Texas Indians: Completely Revised Third Edition. Taylor Trade Publishing, Lanham, Maryland.

Wadley, L.

2005 Putting ochre to the test: replication studies of adhesives that may have been used for hafting tools in the Middle Stone Age. Journal of Human Evolution 49:587-601. 